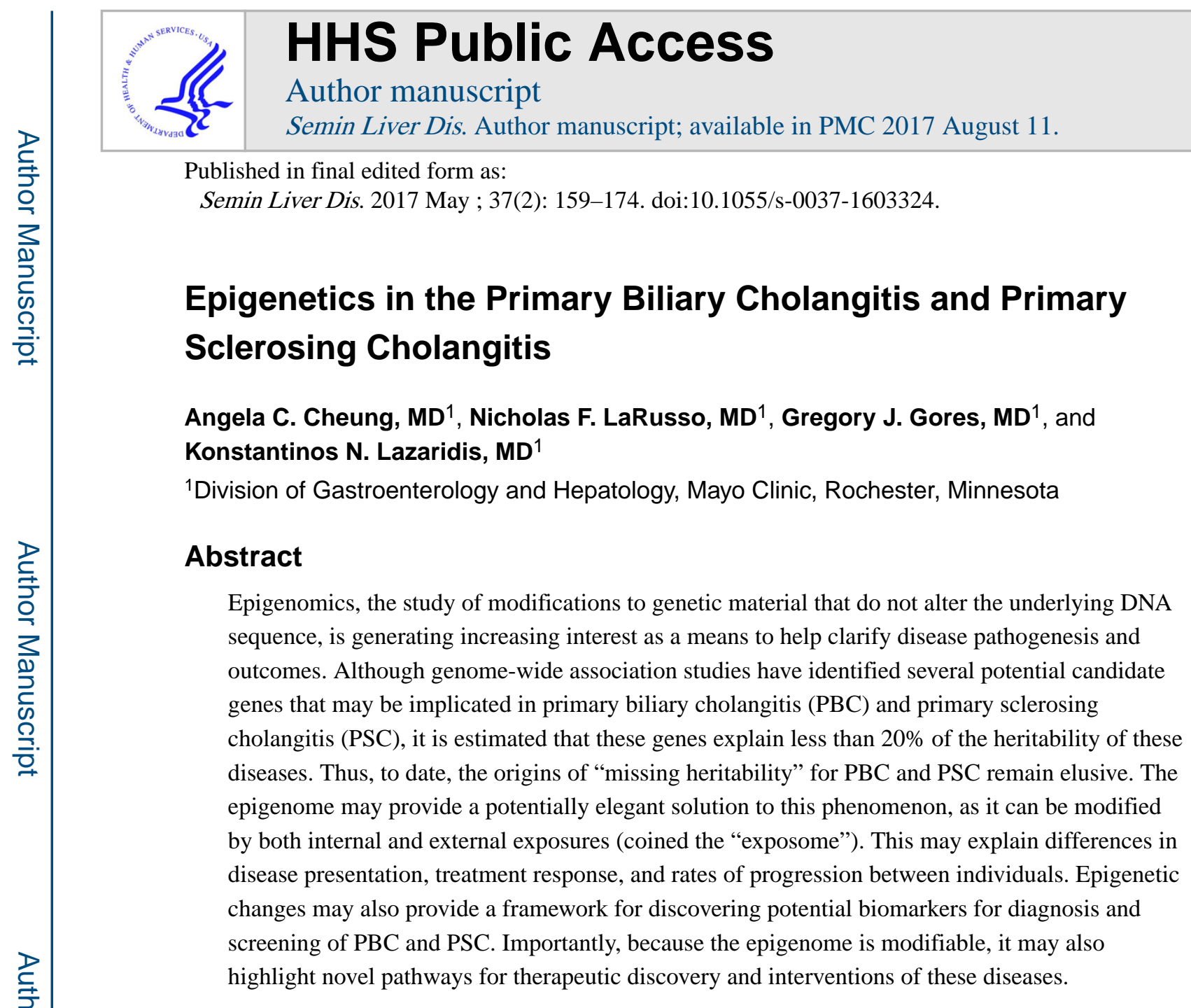

\title{
Keywords
}

cholestatic liver disease; epigenetics; primary biliary cholangitis; primary sclerosing cholangitis

The term "epigenetics" takes its roots from the Greek prefix 'epi', meaning "above."

Epigenetic marks are comprised of modifications in a chromosome that occur "above" the DNA sequence, creating phenotypic changes that are stable and heritable despite lack of alterations to the underlying DNA. ${ }^{1}$ They affect changes in somatic cells and may potentially alter cells in the germ-line. ${ }^{1}$ Epigenetic changes have been implicated in a multitude of diseases, ranging from cancer to obesity to autoimmunity. ${ }^{2-4}$ Despite the widereaching impact of the epigenome (i.e., the sum of epigenetic alterations across the genome), there has been little investigation into this space in primary biliary cholangitis (PBC) and primary sclerosing cholangitis (PSC).

Epigenetics have been espoused as a possible way to explain the "missing heritability" that is not captured by genome-wide association studies (GWAS; i.e., the inherited elements of

Address for correspondence Konstantinos N. Lazaridis, MD, Division of Gastroenterology and Hepatology, Mayo Clinic, 200 First St SW, Rochester, MN 55905 (lazaridis.konstantinos@ mayo.edu).

The authors have no conflicts of interest relevant to this manuscript. 
disease that cannot be resolved with the classical understanding of genetics alone). ${ }^{5}$

Although structural genetic variation may account for this (e.g., deletions, duplications, translocations and inversions etc.), there is evidence that epigenetics may play a role, as discussed herein. ${ }^{6,7}$ One key feature of the epigenome is evidence that it may be modified by prenatal, perinatal, and postnatal exposures (i.e., toxins, drugs, diet, microbiota, air and water pollutants, and even the psychosocial milieu), the totality of which occurs over one's lifetime and is coined the "exposome". ${ }^{8-10}$ Together, the interplay between the exposome and the epigenome in genetically susceptible individuals may contribute to variability in traits, phenotypes, rates of disease progression, and response to therapy (Fig. 1). ${ }^{11}$

In this review, we will summarize the basic mechanisms through which the epigenome is developed and modified, as well as evidence which demonstrates that it is heritable. We will then focus on studies that have implicated the epigenome in PBC and also discuss the potential for the epigenome to improve our understanding of PSC.

\section{Epigenetic Mechanisms}

There are several known mechanisms for epigenetic modifications, including (1) DNA methylation, (2) histone modification, and (3) modification via noncoding RNAs. These mechanisms are not mutually exclusive, but act in concert to maintain or modulate epigenetic signatures, leading to cell-specific programming. An exhaustive discussion of epigenetic mechanisms is beyond the scope of this review. Indeed, our understanding of the epigenome is likely to evolve as new techniques are developed that enable us to more finely interrogate changes not only to DNA, but also RNA. In 2016, for example, epitranscriptomics was announced as Nature Method's "Method of the Year" due to its ability to map the variety of modifications on RNA, which begs the question of how the epigenome, epitranscriptome and genome intersect to fine-tune gene expression. ${ }^{12}$

\section{DNA Methylation}

Methylation occurs in virtually all organisms and provides a mechanism for reversible transcriptional repression that is inheritable, but mutable during development, aging and states of pathology. ${ }^{13}$ DNA methylation is also critical in maintaining homeostatic gene expression in the normal cellular environment. In mammals, methylation generally is limited to $\mathrm{CpG}$ islands, genomic regions that have an abundance of cytosine and guanine nucleotides. ${ }^{14} \mathrm{CpG}$ is lands are located in 60 to $70 \%$ of promoter regions, and are hypothesized to be the means by which promoters are labeled and recognized for transcription (Fig. 2). ${ }^{15}$ Most genes are epigenetic silenced in a constitutive fashion (i.e., 60 $80 \%$ of the 28 million $\mathrm{CpG}$ dinucleotides in the human genome). ${ }^{16}$ One of the most striking examples of epigenetic silencing, which may have relevance in $\mathrm{PBC}$, is that which occurs in the $\mathrm{X}$-chromosome of somatic cells in human females. Here, one $\mathrm{X}$-chromosome is constituently inactivated by hypermethylation, which allows for autosomal imprinting, that is, the variable expression of parental autosomal genes. ${ }^{17}$ Another interesting phenomenon is that $\mathrm{CpG}$ islands can also occur at intergenic or intragenic regions. These are also generally methylated yet overlap with known areas of RNA transcription, suggesting that the majority 
of these CpG islands may be involved in transcription only as "alternate promoters" or during different stages of development. ${ }^{15,18}$

To allow for specialization and functional differentiation, DNA methylation is cell-specific (germ-line vs. somatic), tissue-specific, and even regionally specific, with the same type of cell having $\mathrm{CpG}$ islands with different methylation states (differential methylation) when mapped to different regions of the brain. ${ }^{15,18}$ Methylation also plays a role in maintaining chromosomal and genomic stability, as well as regulating genetic enhancers (a region of DNA that can bind transcription factors, thereby enhancing transcription) and insulators (a region of DNA that prevents inappropriate interactions between neighboring genomic regions). ${ }^{19}$ The lack of methylation has been shown to be vital to the viability of both somatic and cancer cells. ${ }^{20,21}$ DNA methylation is controlled by several key proteins that can be grouped into the categories of "Writers," "Readers" and "Editors."22

\section{DNA Methyltransferases}

In humans, DNA methylation is controlled by DNA methyl-transferases (DNMT), DNMT1, DNMT3A, DNMT3B, and DNMT3L, which exclusively methylate CpG dinucleotides and thus, are considered the "writers" of DNA methylation (Fig. 3). DMNT1, in concert with DNMT3A and DNMT3B, maintains DNA methylation that occurs predominantly during DNA replication. DNMT3A and DNMT3B cause de novo methylation, with the former two unable to methylate active promoters and enhancers. ${ }^{14,23,24}$ DMNTs are necessary for embryonic and neonatal development, and can also protect against apoptosis and proliferation. ${ }^{14,20,21}$

\section{Methyl-CpG Binding Domain Proteins}

Methyl-CpG binding domain (MBD) proteins can be considered the "readers" of DNA methylation as they bind to methylated CpGs. They coordinate the interplay between methylated DNA and histone complexes, thereby leading to the alteration of chromatin structure and transcriptional expression or repression. ${ }^{22}$ MBD proteins bind to single, symmetrically methylated CpGs; to date, eleven members of the MBD protein family have been identified: MeCP2, MBD1, MBD2, MBD3, MBD4, MBD5, MBD6, SETDB1, SETDB2, BAZ2A and BAZ2B. ${ }^{22}$ In addition to a MBD, most of these proteins contain a transcriptional repression domain (TRD), as well as unique domains that allow members to perform specialized functions. MBD proteins can bind to histone acetylases and histone deacetylases, thereby affecting changes in chromatin organization. They may also help direct alternative splicing, where genes may encode several proteins. This may be of particular importance where DNA methylation occurs in intergenic regions. Methyl-CpG binding domain proteins can also bind to members of the ten-eleven translocation (TET) protein family, the "editors" of DNA methylation, further described below.

DNMTs, TET proteins, MBD proteins and histone modification proteins work in concert to cause transcriptional modification. In particular, MBD proteins can act to mobilize epigenetic machinery in a number ways. Examples include (Fig. 4A): (a) binding to TFs (which in turn bind to unmethylated CpG dinucleotides), DNMTs and HDACs, which can deacetylate and methylate histones and DNA respectively, both of which lead to decreased 
transcription, (b) binding directly to specific methylated $\mathrm{CpG}$ dinucleotides, thereby providing an anchor point for HMs, which-methylate histones, and (c) HDACs. Importantly, TET can demethylate DNA at CpGdinucleotides, which decreases binding sites for MBD, but also permits increased transcription. Finally, (d) MBD proteins can also bind to one another, leading to conformational changes in DNA.

\section{Ten-Eleven Translocation Proteins}

The "editors" of DNA methylation, the three mammalian TET proteins (TET1, TET2, TET3), can cause DNA demethylation of $\mathrm{CpG}$ dinucleotides through the successive oxidization of 5-methylcytosine $(5 \mathrm{mC})$ to 5-hydroxymethylcytosine $(5 \mathrm{hmC}), 5$ formylcytosine (5fC), and 5-carboxylcytosine (5caC) (Fig. 3). ${ }^{25}$ Most TET-deficient mouse models are not viable between the embryonic or perinatal stage. TET is also crucial to transcription, as TET $1^{-/}$mice demonstrate dysregulation of $\sim 1000$ genes despite an increase in methylation in less than $1 \%$ of all CpG sites. TET may also be necessary for the development of pluripotent stem cells through the oxidation and demethylation of promoters and enhancers that are essential for reprogramming. ${ }^{25}$

\section{Histone Modification}

Histone proteins provide the anchoring component of the nucleosome, which consists of DNA encircling a histone core 1.67 rotations. ${ }^{26}$ The histone core is an octamer that consists of one pair of each of the main histones: H3, H4, H2A, and H2B (Fig. 4B). Each of the four main histones has variants that confer different functions, but their main structure is comprised of 3 a-helices which are separated by two loops.

Histones mainly function to alter the structural configuration of chromatin. Histones can undergo significant post-translational modification (PTMs; including acetylation, phosphorylation, and methylation), which modulates the stability of the nucleosome, and leads to open chromatin (transcriptionally permissive) or closed chromatin (transcriptionally repressive). Histone acetylation by histone acetylases (HATs), induces DNA transcription, whereas histone deacetylases (HDACs), lead to transcriptional repression. PTMs can also alter binding of proteins which can also in turn enable or repress transcription. They provide incredible transcriptional regulatory capacity, as modifications occur at different amino acid positions and are associated with very different functions. Interestingly, even the same modifications can either lead to transcriptional activation or repression depending on the context, which is likely modulated by different accompanying effector proteins. ${ }^{27}$

Given the numerous histone modifications that can occur, naming conventions have been developed to include the name of the canonical histone (i.e., H3, H4, H2A, and H2B), followed by the single-letter amino acid abbreviation (i.e., "K" for lysine), the amino acid position in the protein (i.e., 27) and finally the modified residue abbreviation (i.e., "me2" for the addition of a dimethyl group). ${ }^{28}$

The modification of histones is coordinated by several pathways. These include specific DNA sequences that can recruit histone-modifying enzymes such as the Polycomb repressive complex 2 (PRC2), which allows for trimethylation of $\mathrm{H} 3 \mathrm{~K} 27 .{ }^{29}$ Small and long 
noncoding RNAs may also bind and direct enzymes that induce PTMs, causing them to localize to histones at specific genomic sites ${ }^{27}$ DNA methylation may also facilitate histone methylation, which in turn can promote methylation of DNA. Histone methylation is thought to undergo global erasure during gametogenesis, yet histone modifications appear to be transmitted both through mitosis and meiosis. ${ }^{27}$

\section{Noncoding RNAs}

There are over 50 varieties of small noncoding RNAs (sncRNAs, 20-25 nt) and long noncoding RNAs (lncRNAs; > $200 \mathrm{nt}$ ) that are created following intergenic and antisense transcription. ${ }^{30,31}$ Noncoding RNAs (ncRNAs) play numerous roles in maintaining epigenetic homeostasis and activating or suppressing transcription (Figs. $4 \mathrm{Ci}-4 \mathrm{Cvii}$ ). IncRNA can bind to complementary base pairs on DNA, preventing the binding of transcriptional machinery such as transcription factors and polymerases (Fig. 4Ci). Conversely, IncRNAs can form RNA scaffolds which provide anchoring points for RNAbinding proteins, such as RNA polymerase II (Fig. 4Cii). They can also bind proteins which can then recruit complexes that modify chromatin (i.e., DNMTs, HMs, PRC2) (Fig. 4Ciii), or alternatively, sequester enzymes involved in chromatin remodelling (Fig. 4Civ). ${ }^{30}$ SncRNAs may also be involved in positive feedback loops, whereby small interfering RNAs (siRNAs) are recruited during active methylation that is catalyzed by enzymes that bind to H3K9me2 or methylated DNA (Fig. 4Cv). These siRNAs then upregulate histone and DNA methylation which in turn recruits additional siRNAs. This is one of the mechanisms postulated to help regulate epigenetic homeostasis. ${ }^{30}$ RNAi pathways may modulate methylation on histones and DNA to repress transcription. ${ }^{30}$ ncRNA can also participate in RNA interference (RNAi) pathways, where microRNAs (miRNAs), a form of sncRNAs, can silence gene expression. This can inhibit incorporation of foreign genetic material Fig. 4Cvi). Another well-known pathway involves the formation of a miRNA via a cleavage process through Dicer, an RNAse III nuclease (Fig. 4Cvii-i). An Argonaute (AGO) protein is then recruited, along with other proteins, creating an RNA-induced silencing complex (RISC) (Fig. 4Cvii-ii), which then cleaves an mRNA segment with the complementary base pair sequence (Fig. 4Cvii-iii). ${ }^{31}$

\section{Epigenetics and "Missing Heritability"}

GWAS have demonstrated that multiple polymorphic loci contribute to disease phenotypes. However, despite the identification of multiple-disease risk alleles, genetic factors collectively convey far less to disease susceptibility than expected (an observation termed "missing heritability"). Most GWAS of complex diseases have been able to explain 20\% of the heritability of these diseases. ${ }^{24,32-36}$ Thus, the question remains whether missing heritability is secondary to the lack of adequate sensitivity, power, and/or discriminant ability of current genome analysis techniques, the complexity of gene-gene or geneenvironment interactions, or whether factors such as the epigenome may be involved. ${ }^{37,38}$

It is now well-recognized that over $90 \%$ of single nucleotide polymorphisms (SNPs) discovered through many GWAS are in noncoding regions ( 43\% are intergenic and $45 \%$ intronic). ${ }^{6}$ One key finding that implicates the epigenome is the discovery that SNPs 
associated with risk alleles are often associated with enhancers. ${ }^{39}$ In a study that evaluated causal variants in 21 autoimmune diseases, $60 \%$ of SNPs were mapped to enhancers of immune cells. ${ }^{40}$ Enhancers have quantitative impacts on gene expression, which implies that SNPs associated with disease may lead to altered gene expression levels rather than protein mutations. ${ }^{39}$ In fact, the number of known enhancers outstrips the number of protein-coding genes by a 100-fold, suggesting that there is tremendous redundancy in the enhancers that regulate protein expression. ${ }^{41,42}$ This allows for plasticity in enhancer activity over time and across cell lineages, which is normally under epigenetic control. ${ }^{43}$

As a result, disease-associated SNPs have been found to be enriched in specific cell types. In rheumatoid arthritis, for example, it has been demonstrated that $\mathrm{T}_{\mathrm{Reg}}$ cells are enriched for an epigenetic mark associated with promoters (trimethylation of lysine 4 of histone $\mathrm{H} 3$; H3K4me3) within rheumatoid arthritis-specific risk loci. Similarly, it has been shown that SNPs found in type-1 diabetes (T1D) map to active enhancers in T cells, B cells, and CD34 ${ }^{+}$ stem cells, and a SNP associated with ankylosing spondylitis mapped to an enhancer located in Th1 cells. 44

The importance of epigenetic changes in type 1 diabetes was recapitulated in a NOD mouse model, where treatment of prediabetic mice with a bromodomain and extraterminal domain (BET) inhibitor prevented the development of diabetes. BET proteins allow recognition of lysine residues on histones and thus permits their modification. ${ }^{45}$ Interestingly, BET inhibitors had no effect on circulating or infiltrating $\mathrm{T}$ cells, but appeared to target pancreatic macrophages, down-regulating NF- $\kappa \mathrm{B}$ associated pathways. ${ }^{45}$ Although this study needs to be replicated more broadly, the implications of this study are twofold: (1) that epigenetic regulation may have a strong role in the etiology of autoimmune disease, and (2) in theory, epigenetics might provide a means of targeting cells involved in disease pathogenesis.

\section{Heritability of the Epigenome}

Another important feature of "missing heritability" is that the changes incurred by epigenetic changes would be required to be, in fact, heritable. Importantly, like the genome, the epigenome is inheritable during mitosis and possibly even meiosis. ${ }^{46}$ It has been shown that while primordial germ cells become largely demethylated during gametogenesis, $40 \%$ of all 5-mC are preserved. ${ }^{47}$ In fact, distinct DNA methylation patterns are retained from oocytes and spermatozoa, with some maternal alleles demonstrating persistent methylation through the blastocyst phase and embryonic development (Fig. 5A). ${ }^{48,49}$ In another example of transgenerational transmission, when gestating rats were exposed to vinclozolin (an antiandrogenic compound), alterations in methylation were demonstrated over four generations of rats despite subsequent generations never having been exposed (Fig. 5B). ${ }^{50}$ Vinclozolin exposure caused over $90 \%$ of all male rats in the F1-F4 generations to demonstrate increased spermatogenic cell apoptosis (a germ cell defect), which was conferred through the male germ line. These changes correlated with methylation changes seen only in offspring of rats exposed to vinclozolin. Similarly, transgenerational inheritance through epigenetic mechanisms has been demonstrated with exposure to dioxin, bisphenol A, DDT, hydrocarbons and tributyltin. ${ }^{51}$ The sncRNAs from sperm also appear to contribute to the generational transmission of epigenetic changes. In one experiment, RNA specific to 
the mouse Kit gene was derived from sperm of mice with mutant Kit and injected into fertilized eggs, leading to nearly $50 \%$ of the offspring developing a stereotypical white tail phenotype which passed down to their offspring (Fig. 5C). ${ }^{52} \mathrm{~A}$ similar effect was noted both in the experimental animals and their offspring when miRNAs that could potentially target Kit mRNA (miR-221 and miR-222) were injected into fertilized eggs.

\section{Epigenetics in Cholangiopathy: Primary Biliary Cholangitis \& Primary Sclerosing Cholangitis}

GWAS in PBC and PSC have demonstrated that each disease shares several overlapping risk loci with other immune-mediated disorders. PBC, for example, shares 14 risk loci with multiple sclerosis, and 9 with both celiac disease and ulcerative colitis. PSC, meanwhile, shares 7 risk loci with ulcerative colitis, Crohn's disease, and diabetes, and 6 with celiac disease. ${ }^{53}$ A recent study used Bayesian analysis to determine the associated risk for five different autoimmune diseases (ankylosing spondylitis, ulcerative colitis, Crohn's disease, psoriasis, PSC) attributable to specific alleles. ${ }^{54}$ Of the 31 loci, 14 increased the risk of all five diseases, suggesting the existence of substantial pleiotropy (i.e., where one gene leads to two or more seemingly unrelated phenotypes). ${ }^{55}$

One potential mechanism for pleiotropy may stem from unique epigenetic changes that occur in response to specific environmental insults. ${ }^{56}$ As epigenetic regulation is important in enhancer activity (as described above), epigenetic alterations due to exposures (such as those exemplified in the mouse experiments with endocrine disruptors), could lead to cellspecific modifications in gene expression, thereby presenting as unique diseases depending on the affected cell population.

Epidemiologic studies have demonstrated numerous environmental associations for a variety of autoimmune disease, including PBC (Table 1) and PSC (Table 2). Both PBC and PSC have been associated with recurrent urinary tract infections (UTIs), which not only favors the classical hypothesis of antigenic exposure as a mechanism for disease pathogenesis, but could also provide a means by which epigenetic disruptions could be caused by microbial pathogens. ${ }^{57-63}$ Smoking, coffee consumption, and hormone replacement therapy (HRT) have been associated with a lower risk of PSC, whereas recurrent UTIs have been associated with an increased risk for PSC. ${ }^{63-68}$ Conversely, smoking, recurrent UTIs, and the use of hair dye or HRT appear to increase the risk of PBC, whereas the use of oral contraceptives appears to be protective. ${ }^{59-62,68,69}$ Additional risk factors and studies are presented in Tables 1 and 2.70

Although the wealth of epidemiologic studies help elucidate possible associations in the development of PBC and PSC, in vivo studies and translational approaches are necessary to confirm the role of exposures in disease pathogenesis. Intriguingly, xenobiotics (foreign chemical compounds present in organisms, which include chemicals found in hair dyes and nail polish) have not only been implicated as a potential agent involved in the pathogenesis of PBC in epidemiologic studies, but also in animal models. Not only do patient sera react to epitopes derived from halogenated organic compounds, but these can also lead to the production of antimitochondrial antibodies (AMAs) in mouse models, which are the putative 
autoantigens pathognomonic for PBC. ${ }^{71,72}$ Similarly, 2-octynoic acid (found in hair dyes and nail polish), can cause AMA generation and histologic changes in mouse models reminiscent of $\mathrm{PBC}$. $^{73,74}$

It has also been demonstrated that epigenetic control is crucial in maintaining bile acid homeostasis, which has implications for both PBC and PSC. Activation of farnesoid X receptor (FXR) is known to decrease bile acid synthesis (through CYP7a1 and CYP8b1) and uptake (through the sodium taurocholate cotransporting polypeptide [NCTP]) via translation of the short heterodimer protein (SHP). ${ }^{75}$ This relationship is mediated by lysine-specific histone demethylase (LSD1), which demethylates both lysine 4 (H3K4me) and lysine 9 (H3K9me), and contains binding sites for FXR that induces LSD1 transcription. ${ }^{76}$ LSD1 then demethylates H3K4me on the gene that encodes for Cyp7a1, Cyp8b1 and NTCP, leading to decreased expression. Consequently, both bile acid production and uptake are decreased, which leads to diminished bile acid hepatotoxicity. This demonstrates that small epigenetic changes can lead to substantial cascade effects, highlighting the critical nature of the epigenome in bile acid homeostasis and disease.

\section{Epigenetics of Primary Biliary Cholangitis}

In many ways, $\mathrm{PBC}$ is considered to be a classical autoimmune disease. Predominantly affecting women (10:1), it is characterized by immunomediated destruction of the small interlobular bile ducts of the liver, leading to cholestasis which manifests as elevated alkaline phosphatase, and in advanced disease leads to hyperbilirubinemia and eventual cirrhosis. ${ }^{77}$ It is largely associated with autoantibodies against the E2 subunit of the pyruvate dehydrogenase complex (PDC-E2), which manifest as AMA positivity in over 90\% of patients. ${ }^{77,78} \mathrm{PBC}$ is also associated with elevated serum IgM levels. ${ }^{79}$ Treatment includes ursodeoxycholic acid (UDCA), a synthetic bile acid, and the recently approved obeticholic acid, a FXR agonist. ${ }^{77,80}$ However, despite treatment with UDCA, up to $40 \%$ of patients may have an inadequate response with persistently elevated alkaline phosphatase and progressive fibrosis, most of whom require an eventual liver transplant. ${ }^{81}$ Similarly, $~ 50 \%$ of subjects treated with obeticholic acid have a suboptimal biochemical response. ${ }^{80}$ Although a differential response to pharmacologic therapies is clearly multifactorial, mediated by sex, genetics, disease stage among other factors, it is possible that epigenetics also plays an important role in mediating treatment response. Further, evaluation of the role of the epigenome may provide alternative routes to therapeutic discovery, particularly for patients with poor response to current therapies.

One of the strongest pieces of evidence for the involvement of nongenetic factors in $\mathrm{PBC}$ is the relatively low concordance for PBC that has been demonstrated in twin studies involving monozygotic and dizygotic twins. In a twin study involving only PBC subjects, 63\% (five of eight) and $0 \%$ (none of eight) of monozygotic and dizygotic twins, respectively, were concordant for PBC. ${ }^{82}$

Several studies have shown that differences in methylation may be involved in the pathogenesis of PBC. One such study evaluated differential methylation using methylation DNA immunoprecipitation (MeDIP) in three sets of twins and eight pairs of sisters. ${ }^{83}$ Although small, the study demonstrated 60 and 14 gene regions for which there was 
differential methylation between the discordant twin sets and between PBC cases and control sisters, respectively. This suggests that their underlying disease risk was modified by epigenetic differences, which in turn were derived from a collection of distinct internal and external exposures. Importantly, though the differentially methylated regions were all significantly hypermethylated as compared with the controls, only SMARCA1 (SWI/SNF related, matrix associated, actin-dependent regulator of chromatin, subfamily A, member 1) was significantly downregulated. Importantly, SMARCA1 encodes for the SWI/SNF family of proteins, which form chromatin remodeling complexes that play vital roles in gene expression, nuclear organization, and chromosomal stability, further implicating epigenetic alterations in the pathogenesis of $\mathrm{PBC} .{ }^{83,84}$

In a hypothesis-driven study, promoter methylation and expression of CD40L were evaluated in patients with $\mathrm{PBC}$. The rationale for this study stemmed from the disproportionate elevation of IgM that manifests in PBC, which has been hypothesized to result from an inappropriate class-switch recombination ${ }^{85}$; a mutant form of the CD40L gene has been found in an X-linked variant of immunodeficiency with hyper-IgM. ${ }^{86}$ Furthermore, overexpression of $\mathrm{CD} 40 \mathrm{~L}$ has been implicated in autoimmunity through three main mechanisms: (1) A decrease in clearance of autoreactive T-cell populations, (2) An increase in T-cell priming, and (3) an upregulation of inflammatory cytokines. ${ }^{85} \mathrm{An}$ evaluation of promoter methylation of $\mathrm{CD} 40 \mathrm{~L}$ demonstrated that $\mathrm{PBC}$ patients had hypomethylation of the CD40L promoter and correspondingly higher expression of CD40L in $\mathrm{CD} 4{ }^{+} \mathrm{T}$ cells, in the absence of any mutations in the CD40L gene. ${ }^{85}$ This difference in methylation was inversely correlated with IgM levels. These findings provide intriguing evidence for the role of hypomethylation in autoreactivity in PBC, tying together hypomethylation of a gene implicated in autoimmunity with functional overexpression of the gene product as well as the characteristic increase in IgM that features prominently in the disease. In further support of the integral role of CD40L in PBC, it has been shown that that there is increased $\mathrm{H} 4$ histone acetylation in the promoter region of $\mathrm{CD} 40 \mathrm{~L}$, which would also lead to increased expression of CD40L. ${ }^{87}$

Primary biliary cholangitis may also be characterized by additional histone modifications that include increased H4 acetylation of promoters for LIGHT, interleukin-17 (IL-17), and interferon- $\gamma$ (IFN- $\gamma$ ) on autoreactive T cells. ${ }^{87}$ Importantly, LIGHT is also critical in autoimmunity, as it is a costimulatory molecule vital to the control of T-cell proliferation. ${ }^{88}$ Overexpression of LIGHT in transgenic mice has been shown to lead to an autoimmune phenotype with autoantibody formation and multiorgan disease with splenomegaly, lymphadenopathy, and glomerulonephritis. ${ }^{88}$ Importantly, the IL-23/IL-17 pathway has been implicated in PBC, with IL-17 positive cells localized to damaged bile ducts and serum of subjects with PBC. ${ }^{89-91}$ Furthermore, the xenobiotic mouse model for PBC, 2-octynoic acid

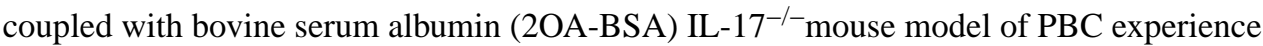
abrogated portal inflammation and bile duct damage as compared with controls. ${ }^{91}$ Chronic IFN- $\gamma$ expression in murine models results in a disease that mimics PBC, with a predilection for females, increased total serum bile acids, portal duct inflammation and antimitochondrial antibody formation. ${ }^{92}$ Interestingly, the role of IFN- $\gamma$ may be bimodal and vary with disease stage. In another xenobiotic murine model of PBC (2-octynoic acid- 
ovalbumin), IFN- $\gamma$ leads to lymphocyte recruitment and activation in early stages of disease; conversely, in late disease, IFN- $\gamma$ appears to inhibit chronic inflammation through IL-30. ${ }^{93}$

The same study demonstrated deacetylation of tumor necrosis factor (TNF)-related apoptosis-inducing ligand (TRAIL), Apo2, and HDAC7A promoters. ${ }^{87}$ TNF-related apoptosis-inducing ligand, as its name suggests, is integral in the induction of apoptosis, but is also thought to inhibit autoimmunity through cell cycle arrest under certain conditions. ${ }^{94}$ Indeed, TRAIL ${ }^{-/}$and TRAIL-receptor ${ }^{-/-}$rodents are more susceptible to acquiring autoimmune arthritis and diabetes after exposure to known induction agents, though they do not develop spontaneous autoimmunity. ${ }^{95}$ Intriguingly, apoptosis of biliary epithelial cells has long been hypothesized to occur in PBC. It is this process that is theorized to lead to the development of AMAs, as AMAs react with PDC-E2 on apoptotic biliary epithelial cells. ${ }^{96}$ Indeed, TRAIL, TRAIL mRNA, and protein levels are elevated in the serum of subjects with PBC as compared with those with hepatitis C, and TRAIL mRNA and protein levels are likewise elevated on circulating leukocytes. ${ }^{97,98}$ These conflicting results suggest that perhaps TRAIL plays a dual role in $\mathrm{PBC}$, one that promotes apoptosis and the development of autoantibodies, and another that promotes susceptibility to autoimmunity.

However, mechanisms that maintain epigenetic homeostasis are complex; thus, it is highly possible that neither differential methylation nor histone modifications alone can explain all differences in gene expression. This was exemplified in a study that evaluated transcript levels in monozygotic twins, of whom only one had PBC. ${ }^{99}$ Affected twins had decreased transcription products of two genes (CLIC2 and PIN4), but these were either partially or variably methylated, and there was no consistent relationship between methylation status and transcript level.

Finally, the most intriguing data regarding $\mathrm{PBC}$ pathogenesis arise from the evaluation of the $\mathrm{X}$ and $\mathrm{Y}$ chromosomes. As mentioned above, $\mathrm{PBC}$ is characterized by a female predominance, which may be due to epigenetic changes linked to the $\mathrm{X}$ chromosome. It is known that $\mathrm{X}$ monosomy occurs constitutively in most healthy females, as $>85 \%$ of the genes on one $\mathrm{X}$ chromosome are epigenetically silenced. ${ }^{100}$ However, women with PBC have a preferential loss of the $\mathrm{X}$ chromosome, meaning that the silenced $\mathrm{X}$ chromosome is more likely to be derived from a specific parental lineage, which is usually random. ${ }^{101}$ This was shown in a study that investigated peripheral blood mononuclear cells of 166 women with PBC, as compared with age-matched controls with (49 women with chronic hepatitis C) and without liver disease (177 healthy women). Using Quantitative Fluorescent PCR (QF-PCR) of the HUMARA locus, located at the androgen receptor gene to determine allelic lineage, it was determined that $39 \%, 17.5 \%$ and $24 \%$ of subjects with PBC, chronic hepatitis $\mathrm{C}$, and controls had an imbalanced allelic dosage. This suggests that one parental allele escapes epigenetic silencing, leading to cell populations that are dominated by an active X-chromosome from a specific parent. This is theorized to effectively lead to an Xlinked disease pattern, with the inherited $\mathrm{X}$-chromosome containing a haplotype that, when it predominates, can lead to the development of PBC. The implication of such a disease model is that random (i.e., equal) epigenetic silencing of both parental alleles is protective against the development of pathology. 
Given the low prevalence of PBC in men, it has been hypothesized that there might be chromosomal differences in male subjects who develop PBC. Compared with sex and agematched controls, men with PBC have a higher frequency of $\mathrm{Y}$ chromosome loss $(1.88 \%$ vs. $1.31 \%, p=0.004) .{ }^{102}$ This association appears to remain consistent with age, though age itself is a predisposing factor for Y chromosome loss. As above, the implication is that the increased loss of one protective allele leads to a predominance of an allele that is characterized by an increased risk of autoimmunity.

In a follow-up study, 30 women with PBC were compared with 30 age-matched controls to determine if there were methylation differences on the $\mathrm{X}$ chromosome. It was demonstrated that CD4 +, CD8 +, and CD14+ cells were differentially methylated at 20, 15, and 19 unique DNA promoters on the X-chromosome. ${ }^{103}$ In particular, FUNDC2 was hypermethylated in $\mathrm{CD} 8+\mathrm{T}$ cells, which resulted in a significant decrease in gene expression. Conversely, CXCR3 was hypomethylated, with an increase in CXCR3 expression, the level of which was associated with the duration of disease. IL1RAPL2 and UBE2A were hypermethylated in CD4+ T cells and CD14+ cells, but there was no difference in gene expression between PBC subjects and controls.

The finding of CXCR3 overexpression is notable as CXCR3 is integral in Th1 cell differentiation. It regulates interactions within lymph nodes between antigen-specific CD4+ $\mathrm{T}$ cells and dendritic cells presenting the same antigen, as well as allows for lymph node localization of activated CD4+ T cells. ${ }^{104}$ The CXCR3 receptor binds three different chemokines, CXCL9, CXCL10, and CXCL11, which facilitate IFN- $\gamma$-dependent T-cell recruitment in autoimmune disorders. ${ }^{105}$

In conclusion, there is evidence that epigenetic changes play a not insignificant role in the pathogenesis of PBC (summarized in Table 3). There remains much to be explored, however, as epigenetics, and relatedly, the exposome, may help elucidate the reasons behind the different disease phenotypes, symptoms, rates of progression, and differing response to treatment.

\section{Epigenetics of Primary Sclerosing Cholangitis}

Primary sclerosing cholangitis is a disease of unknown etiology whereby chronic, progressive inflammation of the large bile ducts causes stricturing and fibrosis. Unlike classical autoimmune diseases, it predominantly affects men (2:1) and is not consistently associated with any known autoantibodies. ${ }^{106,107}$ There is no current treatment, and thus, the median time to liver transplantation is $\sim 12$ to 18 years. ${ }^{108,109} \mathrm{Up}$ to 60 to $80 \%$ of patients with PSC have concomitant inflammatory bowel disease (IBD). ${ }^{106}$ Historically, PSC has been highly associated with ulcerative colitis rather than with Crohn's disease, but there is mounting evidence that the manifestation of IBD in subjects with PSC may be unique. PSCassociated IBD is often right-sided, with rectal sparing and backwash ileitis. ${ }^{110}$ Furthermore, the aforementioned study examining overlapping risk alleles in various autoimmune diseases showed that ulcerative colitis risk alleles were not more prominent even in a subset of patients with PSC, suggesting that PSC-associated colitis has a distinct genetic identity. ${ }^{54}$ 
Primary sclerosing cholangitis is highly associated with malignant transformation for which there are no widely accepted screening algorithms. ${ }^{106,111}$ A Swedish cohort of 604 PSC patients evaluated standardized incidence ratios (SIRs) of malignancies and demonstrated that affected individuals having a higher risk of cholangiocarcinoma (CCA), hepatocellular carcinoma (HCC), gallbladder carcinoma, colorectal carcinoma, and possibly even pancreatic cancer. ${ }^{112}$

There have been no studies performed whose aim is to specifically identify an epigenetic profile for PSC. The previously mentioned study that mapped genetic and epigenetic of causal variants in 21 autoimmune diseases included both PSC and PBC. ${ }^{40}$ Primary sclerosing cholangitis SNPs were enriched in acetylated cis-regulatory elements of Th1 and Th2 cells, whereas PBC was preferentially enriched for B-cell regulatory elements. Notably, most SNPs were coincident with nucleosome-depleted regions, with DNAse hypersensitivity and discrete loss of $\mathrm{H} 3 \mathrm{~K} 27 \mathrm{ac}$ signal, indicating the presence of a transcription factor binding site.

It has been hypothesized that the microbiome, as part of the exposome, may have pathogenic links to PSC, which was recently reviewed. ${ }^{113}$ Overall, there is growing interest in the study of the microbiome in disease pathogenesis, which is considered part of the "internal" exposome. The microbiome is postulated to be linked to causal disease pathways in several ways, including epigenetic mechanisms. For example, some bacteria, such as Helicobacter pylori, may be able to directly alter epigenetic machinery. ${ }^{114}$ Other microbial communities, such as those implicated in colorectal cancer (CRC) and IBD, are believed to mediate disease through differential metabolism of the human diet. ${ }^{56,115}$ This is hypothesized to lead to several downstream effects, including alteration of substrates available to both colonocytes (i.e., short-chain fatty acids) as well as competing microbial communities. ${ }^{56} \mathrm{In}$ turn, these effects may have several consequences, including potentially modifying the epigenome of cells in the intestinal milieu. ${ }^{56,115}$

This relationship has been explored in CRC and IBD, where diets high in fiber have been associated with decreased risk. ${ }^{116,117}$ One of the postulated mechanisms by which this may occur is through the increase of short-chain fatty acids (i.e., butyrate and propionate) following microbial metabolism of undigested carbohydrates ${ }^{56}$ Butyrate is an HDAC inhibitor, and has been shown to be able to inhibit the proliferation of malignant colonocytes but induce proliferation of healthy colonocytes; these paradoxical effects appear to be dependent on both the dose of butyrate as well as the metabolic state of the cell. ${ }^{118} \mathrm{In}$ ulcerative colitis, butyrate uptake and metabolism appear to be impaired, which may lead to an increase in NF- $\mathrm{\kappa B}$-dependent inflammation and disrupt normal epigenetic mechanisms that induce stem cell proliferation. ${ }^{115,119}$ Randomized controlled trials on the use of butyrate enemas, however, have not demonstrated that they are significantly better than placebo, suggesting that butyrate replacement alone may not be sufficient to restore intestinal homeostasis, or that only a subset of patients may benefit from this therapy. ${ }^{120}$ 


\section{The Challenges of Epigenetic-Wide Association Studies and Future Directions}

One of the limitations of the epigenetic studies described above is their cross-sectional nature, making it impossible to disentangle "cause" versus "effect." It is possible that inflammation subsequently causes epigenetic changes; in cancer cell lines and an in vivo colitis model, oxidative stress leads to the formation of a DNMT complex that is associated with gene silencing, and may explain the increased risk of malignancy under inflammatory conditions. ${ }^{121}$ Although the previously described study using a T1D mouse model demonstrates possible evidence that epigenetic changes may be instrumental in disease development, further research is needed in this area. An epigenetic-wide association study in a T1D birth cohort found no correlation between a previously identified T1D methylation profile in purified immune cell populations and cord blood, and thus was unable to differentiate whether these changes occurred before or after T1D development. ${ }^{122}$

To identify causal epigenetic variants, human epigenomic studies require a unique design that distinguishes them from GWAS (well-reviewed elsewhere ${ }^{123}$ ). This includes a wellcharacterized selected patient population followed longitudinally (i.e., nested case-controls, birth cohorts, twin studies), where epigenetic profiles are determined prospectively across preclinical/predisease and postdisease states. ${ }^{123,124}$ Patient cohorts must also be matched or statistically adjusted for confounding variables such as age, sex, treatment, and smoking status, all of which can alter the epigenome. Ideally, studies should also include wellcharacterized cell populations or tissue. By extension, the "normal" epigenome must be longitudinally characterized for each cell type, which is currently the mandate of the Human Epigenome Project (HEP; www.epigenome.org).

Aside from understanding disease pathogenesis, epigenetics may also form the basis of biomarkers for diagnosis, cancer screening, and staging tools, as well as future therapies. Therapeutics that target epigenetic machinery are currently in use (i.e., 5-azacitidine for myelodysplastic syndrome) or under development. ${ }^{125-127}$ There is substantial focus on the use of these drugs in malignant disease, but clinical trials in nonmalignant disease have been lacking. ${ }^{128}$ Likewise, biomarkers have been best studied in malignancy, with DNA methylation markers recently approved for average-risk CRC screening. ${ }^{129}$ Several potential biomarkers have been discovered in benign disease, and though further studies are required before they are put into clinical practice or disease risk models, they would provide a noninvasive means of diagnosis and prognostication. ${ }^{130}$ Epigenetic markers may also have the potential to redefine disease staging; whereas aberrant DNA methylation is likely an early event in carcinogenesis. There is evidence that miRNA changes are specific to stage, ${ }^{131}$ whether there is a corollary in benign disease remains to be seen.

\section{Conclusions}

Cholestatic liver diseases are chronic, progressive diseases of unknown etiology. GWAS have demonstrated several distinct and overlapping risk loci both between PBC and PSC as well as other immunomediated diseases. Evolving evidence suggests that epigenetic alterations may play a role in enriching specific cell-populations to enable pleiotropy. 
Because the majority of risk alleles are in noncoding regions, epigenetics may activate alternate promoters through aberrant demethylation, or through gene-gene interactions. There is currently evidence that the autogenicity of PBC may stem from epigenetic changes, particularly changes in methylation and histone acetylation. Although there is a dearth of evidence of epigenetic changes in PSC, there is likely much that can be gleaned from its investigation, including a deeper understanding of its pathogenesis to the discovery of biomarkers for malignancy screening to treatments and interventions. Unbiased approaches to the epigenome may offer crucial insights into both diseases, leading to several novel therapeutic pipelines.

\section{Acknowledgments}

This work was supported by NIH grants DK63947 (to GJG), NIH/NIDDK DK57993 and the Mayo Center for Cell Signaling in Gastroenterology grant DK84567 (P30) (to NFL), DK80670 and DK84960 (to KNL), the Chris M. Carlos and Catharine N. Jockisch Carlos Foundation for PSC, and the Mayo Clinic.

\section{Abbreviations}

\begin{tabular}{|c|c|}
\hline AMA & antimitochondrial antibodies \\
\hline BET & bromodomain and extra-terminal domain \\
\hline DNMTs & DNA methyltransferases \\
\hline FXR & farnesoid $X$ receptor \\
\hline GWAS & genome-wide association studies \\
\hline HDAC & histone deacetylases \\
\hline HRT & hormone replacement therapy \\
\hline IBD & inflammatory bowel disease \\
\hline IFN & interferon \\
\hline IL & interleukin \\
\hline IncRNAs & long noncoding RNAs \\
\hline LSD1 & lysine-specific histone demethylase \\
\hline MBD & methyl-CpG binding domain \\
\hline mRNA & messenger RNA \\
\hline ncRNAs & noncoding RNAs \\
\hline NCTP & sodium taurocholate cotransporting polypeptide \\
\hline PBC & primary biliary cholangitis \\
\hline PRC2 & polycomb repressive complex 2 \\
\hline
\end{tabular}




$\begin{array}{ll}\text { PSC } & \text { primary sclerosing cholangitis } \\ \text { PTM } & \text { posttranslational modification } \\ \text { RNAi } & \text { RNA interference } \\ \text { SHP } & \text { short heterodimer protein } \\ \text { siRNAs } & \text { small interfering RNAs } \\ \text { SncRNAs } & \text { small noncoding RNAs } \\ \text { SNPs } & \text { single nucleotide polymorphisms } \\ \text { TET } & \text { ten-eleven translocation } \\ \text { TNF } & \text { Tumor necrosis factor } \\ \text { TRAIL } & \text { TNF-related apoptosis-inducing ligand } \\ \text { UDCA } & \text { ursodeoxycholic acid } \\ \text { UTIs } & \text { urinary tract infections }\end{array}$

\section{References}

1. Berger SL, Kouzarides T, Shiekhattar R, Shilatifard A. An operational definition of epigenetics. Genes Dev. 2009; 23(07):781-783. [PubMed: 19339683]

2. Esteller M. Epigenetics in cancer. N Engl J Med. 2008; 358(11):1148-1159. [PubMed: 18337604]

3. Ozanne SE. Epigenetic signatures of obesity. N Engl J Med. 2015; 372(10):973-974. [PubMed: 25738675]

4. Zhang Z, Zhang R. Epigenetics in autoimmune diseases: pathogenesis and prospects for therapy. Autoimmun Rev. 2015; 14(10):854-863. [PubMed: 26026695]

5. Koch L. Epigenetics: an epigenetic twist on the missing heritability of complex traits. Nat Rev Genet. 2014; 15(04):218.

6. Manolio TA. Genomewide association studies and assessment of the risk of disease. N Engl J Med. 2010; 363(02):166-176. [PubMed: 20647212]

7. Tough DF, Prinjha RK. Immune disease-associated variants in gene enhancers point to BET epigenetic mechanisms for therapeutic intervention. Epigenomics. 2016

8. Rappaport SM. Implications of the exposome for exposure science. J Expo Sci Environ Epidemiol. 2011; 21(01):5-9. [PubMed: 21081972]

9. Baccarelli A, Bollati V. Epigenetics and environmental chemicals. Curr Opin Pediatr. 2009; 21(02): 243-251. [PubMed: 19663042]

10. Gudsnuk K, Champagne FA. Epigenetic influence of stress and the social environment. ILAR J. 2012; 53(3-4):279-288. [PubMed: 23744967]

11. Skinner MK. Environmental epigenomics and disease susceptibility. EMBO Rep. 2011; 12(07): 620-622. [PubMed: 21681201]

12. Eisenstein M. Epitranscriptomics: mixed messages. Nat Methods. 2017; 14:15-17.

13. Schübeler D. Function and information content of DNA methylation. Nature. 2015; 517(7534): 321-326. [PubMed: 25592537]

14. Jones PA. Functions of DNA methylation: islands, start sites, gene bodies and beyond. Nat Rev Genet. 2012; 13(07):484-492. [PubMed: 22641018]

15. Illingworth RS, Bird AP. CpG islands-'a rough guide'. FEBS Lett. 2009; 583(11):1713-1720. [PubMed: 19376112] 
16. Rivera CM, Ren B. Mapping human epigenomes. Cell. 2013; 155(01):39-55. [PubMed: 24074860]

17. Reik W, Lewis A. Co-evolution of X-chromosome inactivation and imprinting in mammals. Nat Rev Genet. 2005; 6(05):403-410. [PubMed: 15818385]

18. Maunakea AK, Nagarajan RP, Bilenky M, et al. Conserved role of intragenic DNA methylation in regulating alternative promoters. Nature. 2010; 466(7303):253-257. [PubMed: 20613842]

19. Gaszner M, Felsenfeld G. Insulators: exploiting transcriptional and epigenetic mechanisms. Nat Rev Genet. 2006; 7(09):703-713. [PubMed: 16909129]

20. Jackson-Grusby L, Beard C, Possemato R, et al. Loss of genomic methylation causes p53dependent apoptosis and epigenetic deregulation. Nat Genet. 2001; 27(01):31-39. [PubMed: 11137995]

21. Chen T, Hevi S, Gay F, et al. Complete inactivation of DNMT1 leads to mitotic catastrophe in human cancer cells. Nat Genet. 2007; 39(03):391-396. [PubMed: 17322882]

22. Du Q, Luu PL, Stirzaker C, Clark SJ. Methyl-CpG-binding domain proteins: readers of the epigenome. Epigenomics. 2015; 7(06):1051-1073. [PubMed: 25927341]

23. Robertson KD. DNA methylation and human disease. Nat Rev Genet. 2005; 6(08):597-610. [PubMed: 16136652]

24. Trerotola M, Relli V, Simeone P, Alberti S. Epigenetic inheritance and the missing heritability. Hum Genomics. 2015; 9:17. [PubMed: 26216216]

25. Pastor WA, Aravind L, Rao A. TETonic shift: biological roles of TET proteins in DNA demethylation and transcription. Nat Rev Mol Cell Biol. 2013; 14(06):341-356. [PubMed: 23698584]

26. Venkatesh S, Workman JL. Histone exchange, chromatin structure and the regulation of transcription. Nat Rev Mol Cell Biol. 2015; 16(03):178-189. [PubMed: 25650798]

27. Greer EL, Shi Y. Histone methylation: a dynamic mark in health, disease and inheritance. Nat Rev Genet. 2012; 13(05):343-357. [PubMed: 22473383]

28. Turner BM. Reading signals on the nucleosome with a new nomenclature for modified histones. Nat Struct Mol Biol. 2005; 12(02):110-112. [PubMed: 15702071]

29. Simon JA, Kingston RE. Occupying chromatin: polycomb mechanisms for getting to genomic targets, stopping transcriptional traffic, and staying put. Mol Cell. 2013; 49(05):808-824. [PubMed: 23473600]

30. Holoch D, Moazed D. RNA-mediated epigenetic regulation of gene expression. Nat Rev Genet. 2015; 16(02):71-84. [PubMed: 25554358]

31. Cech TR, Steitz JA. The noncoding RNA revolution-trashing old rules to forge new ones. Cell. 2014; 157(01):77-94. [PubMed: 24679528]

32. Park JH, Wacholder S, Gail MH, et al. Estimation of effect size distribution from genome-wide association studies and implications for future discoveries. Nat Genet. 2010; 42(07):570-575. [PubMed: 20562874]

33. Liu JZ, Anderson CA. Genetic studies of Crohn's disease: past, present and future. Best Pract Res Clin Gastroenterol. 2014; 28(03):373-386. [PubMed: 24913378]

34. Willett WC. Balancing life-style and genomics research for disease prevention. Science. 2002; 296(5568):695-698. [PubMed: 11976443]

35. Hirschfield GM, Chapman RW, Karlsen TH, Lammert F, Lazaridis KN, Mason AL. The genetics of complex cholestatic disorders. Gastroenterology. 2013; 144(07):1357-1374. [PubMed: 23583734]

36. Lichtenstein P, Holm NV, Verkasalo PK, et al. Environmental and heritable factors in the causation of cancer-analyses of cohorts of twins from Sweden, Denmark, and Finland. N Engl J Med. 2000; 343(02):78-85. [PubMed: 10891514]

37. Manolio TA, Collins FS, Cox NJ, et al. Finding the missing herit-ability of complex diseases. Nature. 2009; 461(7265):747-753. [PubMed: 19812666]

38. McCarthy MI, Hirschhorn JN. Genome-wide association studies: potential next steps on a genetic journey. Hum Mol Genet. 2008; 17(R2):R156-R165. [PubMed: 18852205] 
39. Nicolae DL, Gamazon E, Zhang W, Duan S, Dolan ME, Cox NJ. Trait-associated SNPs are more likely to be eQTLs: annotation to enhance discovery from GWAS. PLoS Genet. 2010; 6(04):e1000888. [PubMed: 20369019]

40. Farh KK, Marson A, Zhu J, et al. Genetic and epigenetic fine mapping of causal autoimmune disease variants. Nature. 2015; 518(7539):337-343. [PubMed: 25363779]

41. Wilhelm M, Schlegl J, Hahne H, et al. Mass-spectrometry-based draft of the human proteome. Nature. 2014; 509(7502):582-587. [PubMed: 24870543]

42. Coppola CJC, Ramaker R, Mendenhall EM. Identification and function of enhancers in the human genome. Hum Mol Genet. 2016; 25(R2):R190-R197. [PubMed: 27402881]

43. Ong CT, Corces VG. Enhancer function: new insights into the regulation of tissue-specific gene expression. Nat Rev Genet. 2011; 12(04):283-293. [PubMed: 21358745]

44. Onengut-Gumuscu S, Chen WM, Burren O, et al. Type 1 Diabetes Genetics Consortium. Fine mapping of type 1 diabetes susceptibility loci and evidence for colocalization of causal variants with lymphoid gene enhancers. Nat Genet. 2015; 47(04):381-386. [PubMed: 25751624]

45. Fu W, Farache J, Clardy SM, et al. Epigenetic modulation of type-1 diabetes via a dual effect on pancreatic macrophages and $\beta$ cells. eLife. 2014; 3:e04631. [PubMed: 25407682]

46. Skinner MK. Endocrine disruptors in 2015: Epigenetic transgenerational inheritance. Nat Rev Endocrinol. 2016; 12(02):68-70. [PubMed: 26585656]

47. Szyf M. Nongenetic inheritance and transgenerational epigenetics. Trends Mol Med. 2015; 21(02): 134-144. [PubMed: 25601643]

48. Borgel J, Guibert S, Li Y, et al. Targets and dynamics of promoter DNA methylation during early mouse development. Nat Genet. 2010; 42(12):1093-1100. [PubMed: 21057502]

49. Fulka H, Mrazek M, Tepla O, Fulka J Jr. DNA methylation pattern in human zygotes and developing embryos. Reproduction. 2004; 128(06):703-708. [PubMed: 15579587]

50. Anway MD, Cupp AS, Uzumcu M, Skinner MK. Epigenetic trans-generational actions of endocrine disruptors and male fertility. Science. 2005; 308(5727):1466-1469. [PubMed: 15933200]

51. Schuster A, Skinner MK, Yan W. Ancestral vinclozolin exposure alters the epigenetic transgenerational inheritance of sperm small noncoding RNAs. Environ Epigenet. 2016; 2:1-10.

52. Rassoulzadegan M, Grandjean V, Gounon P, Vincent S, Gillot I, Cuzin F. RNA-mediated nonmendelian inheritance of an epigenetic change in the mouse. Nature. 2006; 441(7092):469-474. [PubMed: 16724059]

53. Mells GF, Kaser A, Karlsen TH. Novel insights into autoimmune liver diseases provided by genome-wide association studies. J Autoimmun. 2013; 46:41-54. [PubMed: 23931959]

54. Ellinghaus D, Jostins L, Spain SL, et al. International IBD Genetics Consortium (IIBDGC); International Genetics of Ankylosing Spondylitis Consortium (IGAS); International PSC Study Group (IPSCSG); Genetic Analysis of Psoriasis Consortium (GAPC); Psoriasis Association Genetics Extension (PAGE). Analysis of five chronic inflammatory diseases identifies 27 new associations and highlights disease-specific patterns at shared loci. Nat Genet. 2016; 48(05):510518. [PubMed: 26974007]

55. Sivakumaran S, Agakov F, Theodoratou E, et al. Abundant pleiotropy in human complex diseases and traits. Am J Hum Genet. 2011; 89(05):607-618. [PubMed: 22077970]

56. Hullar MA, Fu BC. Diet, the gut microbiome, and epigenetics. Cancer J. 2014; 20(03):170-175. [PubMed: 24855003]

57. Paschos K, Allday MJ. Epigenetic reprogramming of host genes in viral and microbial pathogenesis. Trends Microbiol. 2010; 18(10):439-447. [PubMed: 20724161]

58. Al Akeel R. Role of epigenetic reprogramming of host genes in bacterial pathogenesis. Saudi J Biol Sci. 2013; 20(04):305-309. [PubMed: 24235865]

59. Howel D, Fischbacher CM, Bhopal RS, Gray J, Metcalf JV, James OF. An exploratory populationbased case-control study of primary biliary cirrhosis. Hepatology. 2000; 31(05):1055-1060. [PubMed: 10796879]

60. Parikh-Patel A, Gold EB, Worman H, Krivy KE, Gershwin ME. Risk factors for primary biliary cirrhosis in a cohort of patients from the united states. Hepatology. 2001; 33(01):16-21. [PubMed: 11124815] 
61. Gershwin ME, Selmi C, Worman HJ, et al. USA PBC Epidemiology Group. Risk factors and comorbidities in primary biliary cirrhosis: a controlled interview-based study of 1032 patients. Hepatology. 2005; 42(05):1194-1202. [PubMed: 16250040]

62. Corpechot C, Chrétien Y, Chazouillères O, Poupon R. Demographic, lifestyle, medical and familial factors associated with primary biliary cirrhosis. J Hepatol. 2010; 53(01):162-169. [PubMed: 20471130]

63. Eaton JE, Juran BD, Atkinson EJ, et al. A comprehensive assessment of environmental exposures among 1000 North American patients with primary sclerosing cholangitis, with and without inflammatory bowel disease. Aliment Pharmacol Ther. 2015; 41(10):980-990. [PubMed: 25783671]

64. Loftus EV Jr, Sandborn WJ, Tremaine WJ, et al. Primary sclerosing cholangitis is associated with nonsmoking: a case-control study. Gastroenterology. 1996; 110(05):1496-1502. [PubMed: 8613055]

65. van Erpecum KJ, Smits SJ, van de Meeberg PC, et al. Risk of primary sclerosing cholangitis is associated with nonsmoking behavior. Gastroenterology. 1996; 110(05):1503-1506. [PubMed: 8613056]

66. Mitchell SA, Thyssen M, Orchard TR, Jewell DP, Fleming KA, Chapman RW. Cigarette smoking, appendectomy, and tonsillectomy as risk factors for the development of primary sclerosing cholangitis: a case control study. Gut. 2002; 51(04):567-573. [PubMed: 12235082]

67. Andersen IM, Tengesdal G, Lie BA, Boberg KM, Karlsen TH, Hov JR. Effects of coffee consumption, smoking, and hormones on risk for primary sclerosing cholangitis. Clin Gastroenterol Hepatol. 2014; 12(06):1019-1028. [PubMed: 24076415]

68. Lammert C, Juran BD, Schlicht E, et al. Reduced coffee consumption among individuals with primary sclerosing cholangitis but not primary biliary cirrhosis. Clin Gastroenterol Hepatol. 2014; 12(09):1562-1568. [PubMed: 24440215]

69. Prince MI, Ducker SJ, James OF. Case-control studies of risk factors for primary biliary cirrhosis in two United Kingdom populations. Gut. 2010; 59(04):508-512. [PubMed: 20332522]

70. Lammert C, Nguyen DL, Juran BD, et al. Questionnaire based assessment of risk factors for primary biliary cirrhosis. Dig Liver Dis. 2013; 45(07):589-594. [PubMed: 23490343]

71. Long SA, Quan C, Van de Water J, et al. Immunoreactivity of organic mimeotopes of the E2 component of pyruvate dehydrogenase: connecting xenobiotics with primary biliary cirrhosis. J Immunol. 2001; 167(05):2956-2963. [PubMed: 11509645]

72. Leung PS, Quan C, Park O, et al. Immunization with a xenobiotic 6-bromohexanoate bovine serum albumin conjugate induces antimitochondrial antibodies. J Immunol. 2003; 170(10):5326-5332. [PubMed: 12734383]

73. Wakabayashi K, Lian ZX, Leung PS, et al. Loss of tolerance in C57BL/6 mice to the autoantigen E2 subunit of pyruvate dehydrogenase by a xenobiotic with ensuing biliary ductular disease. Hepatology. 2008; 48(02):531-540. [PubMed: 18563844]

74. Wakabayashi K, Yoshida K, Leung PS, et al. Induction of autoimmune cholangitis in non-obese diabetic (NOD). 1101 mice following a chemical xenobiotic immunization. Clin Exp Immunol. 2009; 155(03):577-586. [PubMed: 19094117]

75. Schaap FG, Trauner M, Jansen PL. Bile acid receptors as targets for drug development. Nat Rev Gastroenterol Hepatol. 2014; 11(01):55-67. [PubMed: 23982684]

76. Kim YC, Fang S, Byun S, Seok S, Kemper B, Kemper JK. Farnesoid X receptor-induced lysinespecific histone demethylase reduces hepatic bile acid levels and protects the liver against bile acid toxicity. Hepatology. 2015; 62(01):220-231. [PubMed: 25545350]

77. Nguyen DL, Juran BD, Lazaridis KN. Primary biliarycirrhosis. Best Pract Res Clin Gastroenterol. 2010; 24(05):647-654. [PubMed: 20955967]

78. Walker JG, Doniach D, Roitt IM, Sherlock S. Serological tests in diagnosis of primary biliary cirrhosis. Lancet. 1965; 1(7390):827-831. [PubMed: 14263538]

79. Lindor KD, Gershwin ME, Poupon R, Kaplan M, Bergasa NV, Heathcote EJ. American Association for Study of Liver Diseases. Primary biliary cirrhosis. Hepatology. 2009; 50(01):291308. [PubMed: 19554543] 
80. Nevens F, Andreone P, Mazzella G, et al. POISE Study Group. A placebo-controlled trial of obeticholic acid in primary biliary cholangitis. N Engl J Med. 2016; 375(07):631-643. [PubMed: 27532829]

81. Parés A. Therapy of primary biliary cirrhosis: novel approaches for patients with suboptimal response to ursodeoxycholic acid. Dig Dis. 2015; 33(Suppl 2):125-133. [PubMed: 26642350]

82. Selmi C, Mayo MJ, Bach N, et al. Primary biliary cirrhosis in monozygotic and dizygotic twins: genetics, epigenetics, and environment. Gastroenterology. 2004; 127(02):485-492. [PubMed: 15300581]

83. Selmi C, Cavaciocchi F, Lleo A, et al. Genome-wide analysis of DNA methylation, copy number variation, and gene expression in monozygotic twins discordant for primary biliary cirrhosis. Front Immunol. 2014; 5(1):28. [PubMed: 24570676]

84. Euskirchen GM, Auerbach RK, Davidov E, et al. Diverse roles and interactions of the SWI/SNF chromatin remodeling complex revealed using global approaches. PLoS Genet. 2011; 7(03):e1002008. [PubMed: 21408204]

85. Lleo A, Liao J, Invernizzi P, et al. Immunoglobulin M levels inversely correlate with CD40 ligand promoter methylation in patients with primary biliary cirrhosis. Hepatology. 2012; 55(01):153160. [PubMed: 21898485]

86. Notarangelo LD, Hayward AR. X-linked immunodeficiency with hyper-IgM (XHIM). Clin Exp Immunol. 2000; 120(03):399-405. [PubMed: 10844515]

87. Hu Z, Huang Y, Liu Y, et al. $\beta$-Arrestin 1 modulates functions of autoimmune T cells from primary biliary cirrhosis patients. J Clin Immunol. 2011; 31(03):346-355. [PubMed: 21243522]

88. Wang J, Lo JC, Foster A, et al. The regulation of T cell homeostasis and autoimmunity by T cellderived LIGHT. J Clin Invest. 2001; 108(12):1771-1780. [PubMed: 11748260]

89. Harada K, Shimoda S, Sato Y, Isse K, Ikeda H, Nakanuma Y. Periductal interleukin-17 production in association with biliary innate immunity contributes to the pathogenesis of cholangiopathy in primary biliary cirrhosis. Clin Exp Immunol. 2009; 157(02):261-270. [PubMed: 19604266]

90. Rong G, Zhou Y, Xiong Y, et al. Imbalance between T helper type 17 and T regulatory cells in patients with primary biliary cirrhosis: the serum cytokine profile and peripheral cell population. Clin Exp Immunol. 2009; 156(02):217-225. [PubMed: 19302244]

91. Yang CY, Ma X, Tsuneyama K, et al. IL-12/Th1 and IL-23/Th17 biliary microenvironment in primary biliary cirrhosis: implications for therapy. Hepatology. 2014; 59(05):1944-1953. [PubMed: 24375552]

92. Bae HR, Leung PS, Tsuneyama K, et al. Chronic expression of interferon-gamma leads to murine autoimmune cholangitis with a female predominance. Hepatology. 2016; 64(04):1189-1201. [PubMed: 27178326]

93. Syu BJ, Loh CE, Hsueh YH, Gershwin ME, Chuang YH. Dual roles of IFN- $\gamma$ and IL-4 in the natural history of murine autoimmune cholangitis: IL-30 and implications for precision medicine. Sci Rep. 2016; 6:34884. [PubMed: 27721424]

94. Mackay F, Kalled SL. TNF ligands and receptors in autoimmunity: an update. Curr Opin Immunol. 2002; 14(06):783-790. [PubMed: 12413530]

95. Falschlehner C, Schaefer U, Walczak H. Following TRAIL's path in the immune system. Immunology. 2009; 127(02):145-154. [PubMed: 19476510]

96. Lleo A, Selmi C, Invernizzi P, et al. Apotopes and the biliary specificity of primary biliary cirrhosis. Hepatology. 2009; 49(03):871-879. [PubMed: 19185000]

97. Pelli N, Floreani A, Torre F, et al. Soluble apoptosis molecules in primary biliary cirrhosis: analysis and commitment of the Fas and tumour necrosis factor-related apoptosis-inducing ligand systems in comparison with chronic hepatitis C. Clin Exp Immunol. 2007; 148(01):85-89. [PubMed: 17302732]

98. Liang Y, Yang Z, Li C, Zhu Y, Zhang L, Zhong R. Characterisation of TNF-related apoptosisinducing ligand in peripheral blood in patients with primary biliary cirrhosis. Clin Exp Med. 2008; 8(01):1-7. [PubMed: 18385934]

99. Mitchell MM, Lleo A, Zammataro L, et al. Epigenetic investigation of variably X chromosome inactivated genes in monozygotic female twins discordant for primary biliary cirrhosis. Epigenetics. 2011; 6(01):95-102. [PubMed: 20864813] 
100. Carrel L, Willard HF. X-inactivation profile reveals extensive variability in X-linked gene expression in females. Nature. 2005; 434(7031):400-404. [PubMed: 15772666]

101. Miozzo M, Selmi C, Gentilin B, et al. Preferential X chromosome loss but random inactivation characterize primary biliary cirrhosis. Hepatology. 2007; 46(02):456-462. [PubMed: 17659578]

102. Lleo A, Oertelt-Prigione S, Bianchi I, et al. Y chromosome loss in male patients with primary biliary cirrhosis. J Autoimmun. 2013; 41:87-91. [PubMed: 23375847]

103. Lleo A, Zhang W, Zhao M, et al. PBC Epigenetic Study Group. DNA methylation profiling of the $\mathrm{X}$ chromosome reveals an aberrant demethylation on CXCR3 promoter in primary biliary cirrhosis. Clin Epigenetics. 2015; 7:61. [PubMed: 26150899]

104. Groom JR, Richmond J, Murooka TT, et al. CXCR3 chemokine receptor-ligand interactions in the lymph node optimize CD4+ T helper 1 cell differentiation. Immunity. 2012; 37(06):1091-1103. [PubMed: 23123063]

105. Groom JR, Luster AD. CXCR3 in T cell function. Exp Cell Res. 2011; 317(05):620-631. [PubMed: 21376175]

106. Chapman R, Fevery J, Kalloo A, et al. American Association for the Study of Liver Diseases. Diagnosis and management of primary sclerosing cholangitis. Hepatology. 2010; 51(02):660678. [PubMed: 20101749]

107. Boonstra K, Beuers U, Ponsioen CY. Epidemiology of primary sclerosing cholangitis and primary biliary cirrhosis: a systematic review. J Hepatol. 2012; 56(05):1181-1188. [PubMed: 22245904]

108. Wiesner RH, Grambsch PM, Dickson ER, et al. Primary sclerosing cholangitis: natural history, prognostic factors and survival analysis. Hepatology. 1989; 10(04):430-436. [PubMed: 2777204]

109. Ponsioen CY, Vrouenraets SM, Prawirodirdjo W, et al. Natural history of primary sclerosing cholangitis and prognostic value of cholangiography in a Dutch population. Gut. 2002; 51(04): 562-566. [PubMed: 12235081]

110. Loftus EV Jr, Harewood GC, Loftus CG, et al. PSC-IBD: a unique form of inflammatory bowel disease associated with primary sclerosing cholangitis. Gut. 2005; 54(01):91-96. [PubMed: 15591511]

111. European Association for the Study of the Liver. EASL Clinical Practice Guidelines: management of cholestatic liver diseases. J Hepatol. 2009; 51(02):237-267. [PubMed: 19501929]

112. Bergquist A, Ekbom A, Olsson R, et al. Hepatic and extrahepatic malignancies in primary sclerosing cholangitis. J Hepatol. 2002; 36(03):321-327. [PubMed: 11867174]

113. Ali AH, Carey EJ, Lindor KD. The microbiome and primary sclerosing cholangitis. Semin Liver Dis. 2016; 36(04):340-348. [PubMed: 27997974]

114. Ding SZ, Goldberg JB, Hatakeyama M. Helicobacter pylori infection, oncogenic pathways and epigenetic mechanisms in gastric carcinogenesis. Future Oncol. 2010; 6(05):851-862. [PubMed: 20465395]

115. Fofanova TY, Petrosino JF, Kellermayer R. Microbiome-epigenome interactions and the environmental origins of inflammatory bowel diseases. J Pediatr Gastroenterol Nutr. 2016; 62(02):208-219. [PubMed: 26308318]

116. Aune D, Chan DS, Lau R, et al. Dietary fibre, whole grains, and risk of colorectal cancer: systematic review and dose-response meta-analysis of prospective studies. BMJ. 2011; 343:d6617. [PubMed: 22074852]

117. Hou JK, Abraham B, El-Serag H. Dietary intake and risk of developing inflammatory bowel disease: a systematic review of the literature. Am J Gastroenterol. 2011; 106(04):563-573. [PubMed: 21468064]

118. Donohoe DR, Collins LB, Wali A, Bigler R, Sun W, Bultman SJ. The Warburg effect dictates the mechanism of butyrate-mediated histone acetylation and cell proliferation. Mol Cell. 2012; 48(04):612-626. [PubMed: 23063526]

119. Mali P, Chou BK, Yen J, et al. Butyrate greatly enhances derivation of human induced pluripotent stem cells by promoting epigenetic remodeling and the expression of pluripotency-associated genes. Stem Cells. 2010; 28(04):713-720. [PubMed: 20201064]

120. Lawrance IC. Topical agents for idiopathic distal colitis and proctitis. J Gastroenterol Hepatol. 2011; 26(01):36-43. [PubMed: 21175791] 
121. O'Hagan HM, Wang W, Sen S, et al. Oxidative damage targets complexes containing DNA methyltransferases, SIRT1, and poly-comb members to promoter CpG Islands. Cancer Cell. 2011; 20(05):606-619. [PubMed: 22094255]

122. Paul DS, Teschendorff AE, Dang MA, et al. Increased DNA methylation variability in type 1 diabetes across three immune effector cell types. Nat Commun. 2016; 7:13555. [PubMed: 27898055]

123. Mill J, Heijmans BT. From promises to practical strategies in epigenetic epidemiology. Nat Rev Genet. 2013; 14(08):585-594. [PubMed: 23817309]

124. Viera AJ. Predisease: when does it make sense? Epidemiol Rev. 2011; 33:122-134. [PubMed: 21624963]

125. Heerboth S, Lapinska K, Snyder N, Leary M, Rollinson S, Sarkar S. Use of epigenetic drugs in disease: an overview. Genet Epigenet. 2014; 6:9-19. [PubMed: 25512710]

126. Ahuja N, Sharma AR, Baylin SB. Epigenetic Therapeutics: A New Weapon in the War Against Cancer. Annu Rev Med. 2016; 67:73-89. [PubMed: 26768237]

127. Kaminskas E, Farrell AT, Wang YC, Sridhara R, Pazdur R. FDA drug approval summary: azacitidine (5-azacytidine, Vidaza) for injectable suspension. Oncologist. 2005; 10(03):176-182. [PubMed: 15793220]

128. Mau T, Yung R. Potential of epigenetic therapies in non-cancerous conditions. Front Genet. 2014; 5:438. [PubMed: 25566322]

129. Imperiale TF, Ransohoff DF, Itzkowitz SH. Multitarget stool DNA testing for colorectal-cancer screening. N Engl J Med. 2014; 371(02):187-188.

130. Mikeska T, Craig JM. DNA methylation biomarkers: cancer and beyond. Genes (Basel). 2014; 5(03):821-864. [PubMed: 25229548]

131. Olson P, Lu J, Zhang H, et al. MicroRNA dynamics in the stages of tumorigenesis correlate with hallmark capabilities of cancer. Genes Dev. 2009; 23(18):2152-2165. [PubMed: 19759263] 


\section{Key Points}

- The epigenome is comprised of heritable changes occurring upon the genome that lead to phenotypic changes without altering the underlying DNA sequence.

- The epigenome may provide an explanation for the disconnect between the low risk associated with the large number of susceptibility loci identified by GWAS and the much higher magnitude of calculated attributable heritability.

- The epigenome, being modifiable, may be altered by numerous external and internal factors (the totality of which is included in the term "exposome"), thus presenting a vast new area of inquiry into the cause of disease in susceptible individuals.

- In PBC, both animal models and human studies have suggested an association between environmental exposure and disease, as well as epigenetic modifications and disease pathogenesis.

- Despite associations between exposures and the risk of PSC, there have been no studies evaluating potential epigenetic changes that may be involved, thus this is an area that may expand our understanding of the pathogenesis of PSC, thereby opening doors to new treatment modalities. 


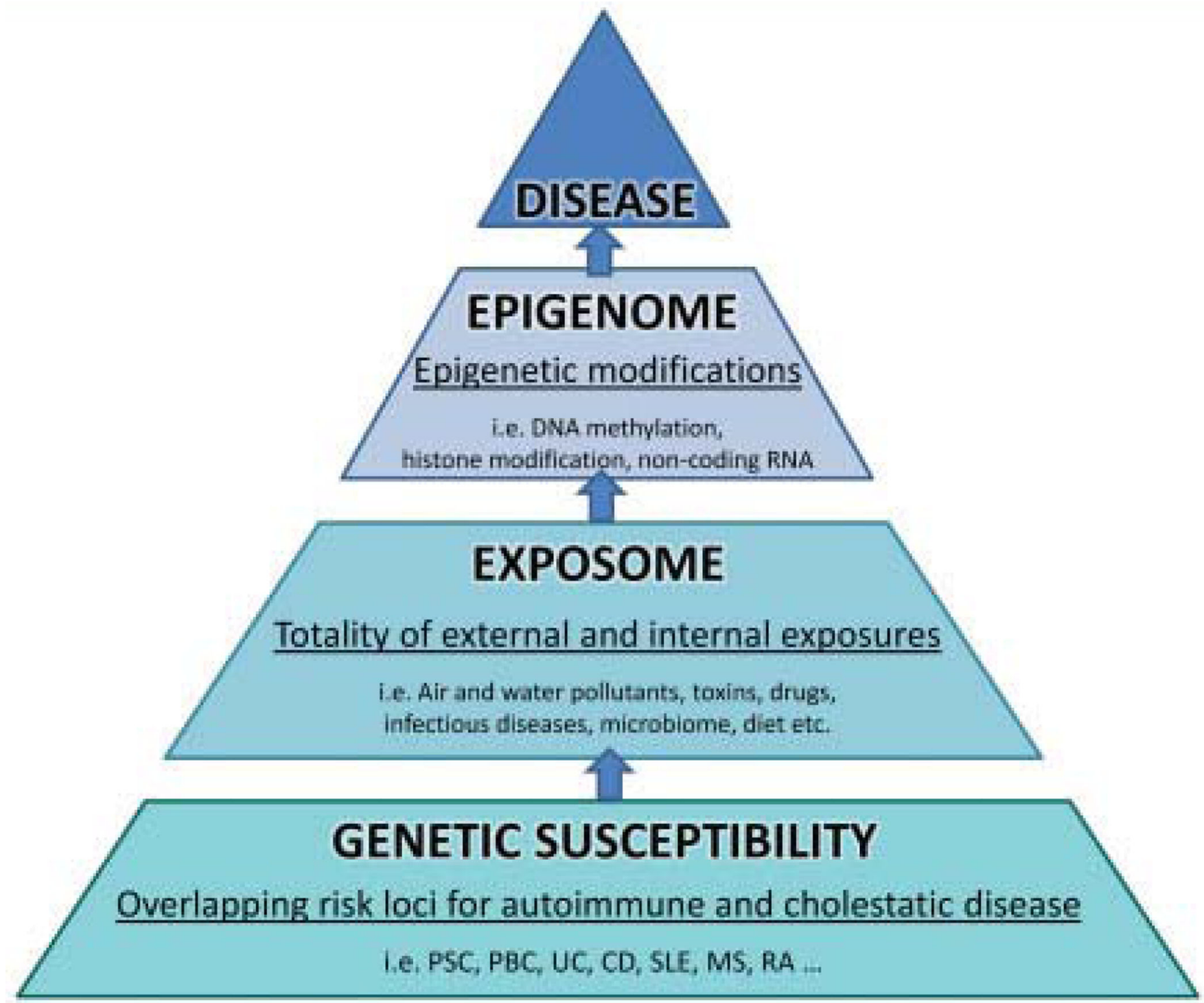

Fig. 1.

Factors involved in the development of non-Mendelian diseases. The exposome, which is composed of all external and internal exposures prior to the development of disease, can, in genetically susceptible individuals, lead to epigenetic modifications, disrupting homeostasis and causing disease. CD, Crohn's disease; MS, multiple sclerosis; PBC, primary biliary cholangitis; PSC, primary sclerosing cholangitis; RA, rheumatoid arthritis; SLE, systemic lupus erythematosus; UC, ulcerative colitis. 


\section{DNA methylation}

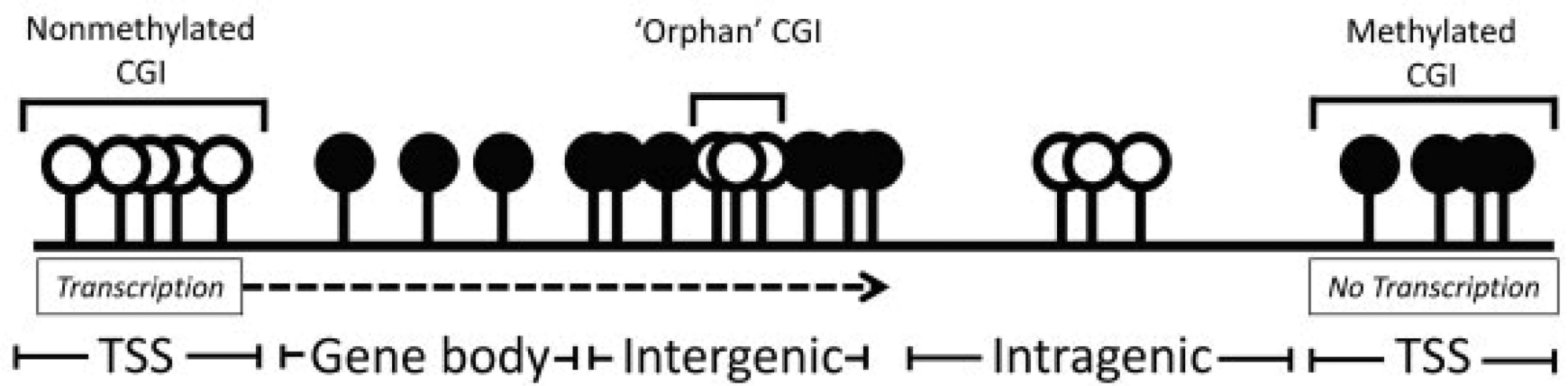

Fig. 2.

DNA methylation. Genes that are actively transcribed are characterized by nonmethylated $\mathrm{CpG}$ islands at the TSS. Nonmethylated $\mathrm{CpG}$ islands may also occur in intergenic regions, and these "orphan" CpG islands are hypothesized to be "alternate promoters" or transcriptionally active during different states such as development. Open circles, nonmethylated $\mathrm{CpG}$ islands; Filled circles, methylated $\mathrm{CpG}$ islands. $\mathrm{CpG}$, cytosine guanine dinucleotide; TSS, transcription start site. 


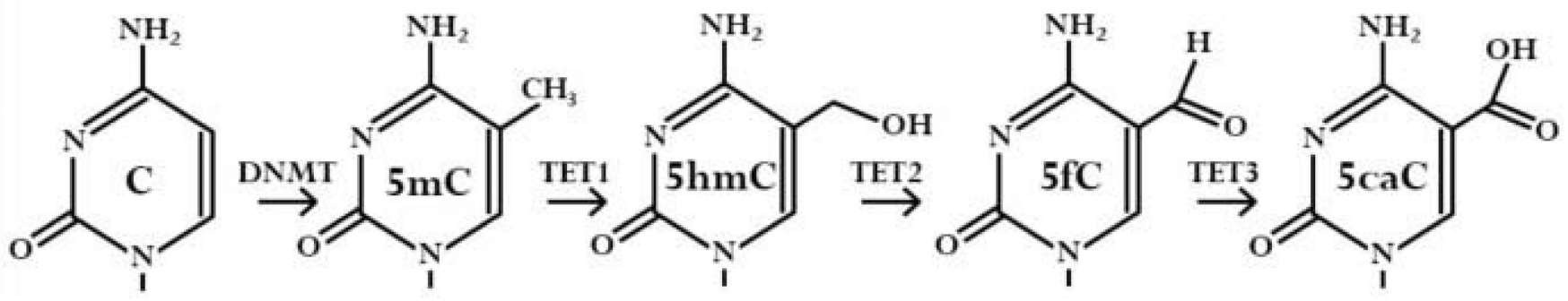

Fig. 3.

DNMTs and TET proteins. DNMT leads to methylation of $\mathrm{CpG}$ dinucleotides. Meanwhile, TET leads to DNA demethylation of $\mathrm{CpG}$ dinucleotides through the successive oxidization of $5 \mathrm{mC}$ to $5 \mathrm{hmC}, 5 \mathrm{fC}$ and $5 \mathrm{caC}$. 5caC, 5-carboxylcytosine; 5fC, 5-formylcytosine; 5hmC, 5hydroxymethylcytosine; 5mC, 5-methylcytosine, DNMT, DNA methyltransferase; TET, teneleven translocation. 


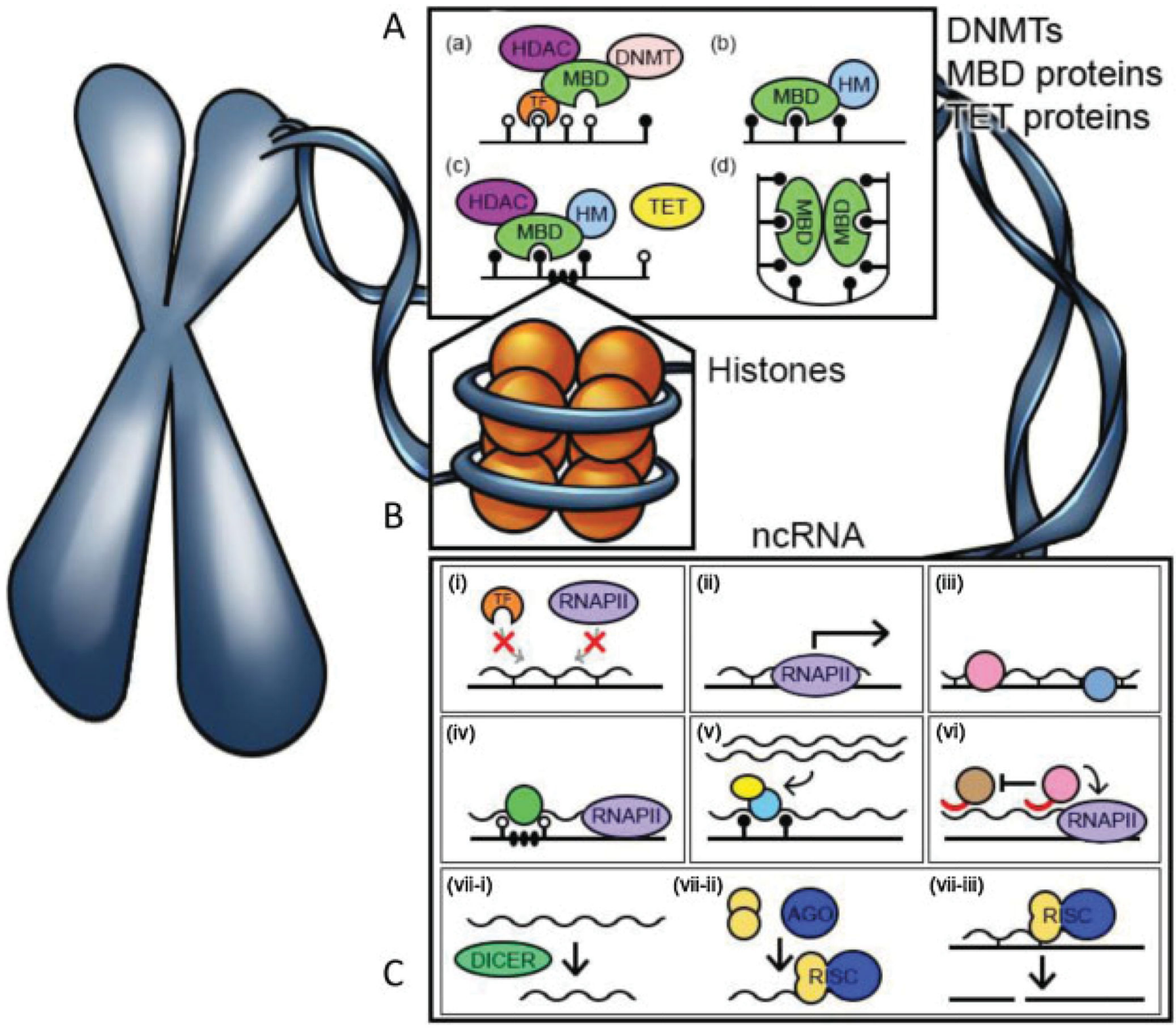

Fig. 4.

(A-C) Epigenetic mechanisms. DNMTs, TET proteins, MBD proteins and histone modification proteins work in concert to cause transcriptional modification. Like MDB proteins, both short and long ncRNA (sncRNA and lncRNA) can interact with different proteins to play a number of roles in epigenetic control. Flat arrow, inhibited pathway. AGO, Argonaute protein; DNMT, DNA methyltransferase; HDAC, histone deactylase; HM, histone methylase; lncRNA, long non-coding RNA; MBD, methyl binding domain (protein); mRNA, messenger RNA; RISC, RNA-induced silencing complex; RNAPII, RNApolymerase II; siRNA, small interfering RNA; sncRNA, short non-coding RNA; TET, Teneleven translocation (protein); TF, transcription factor. 


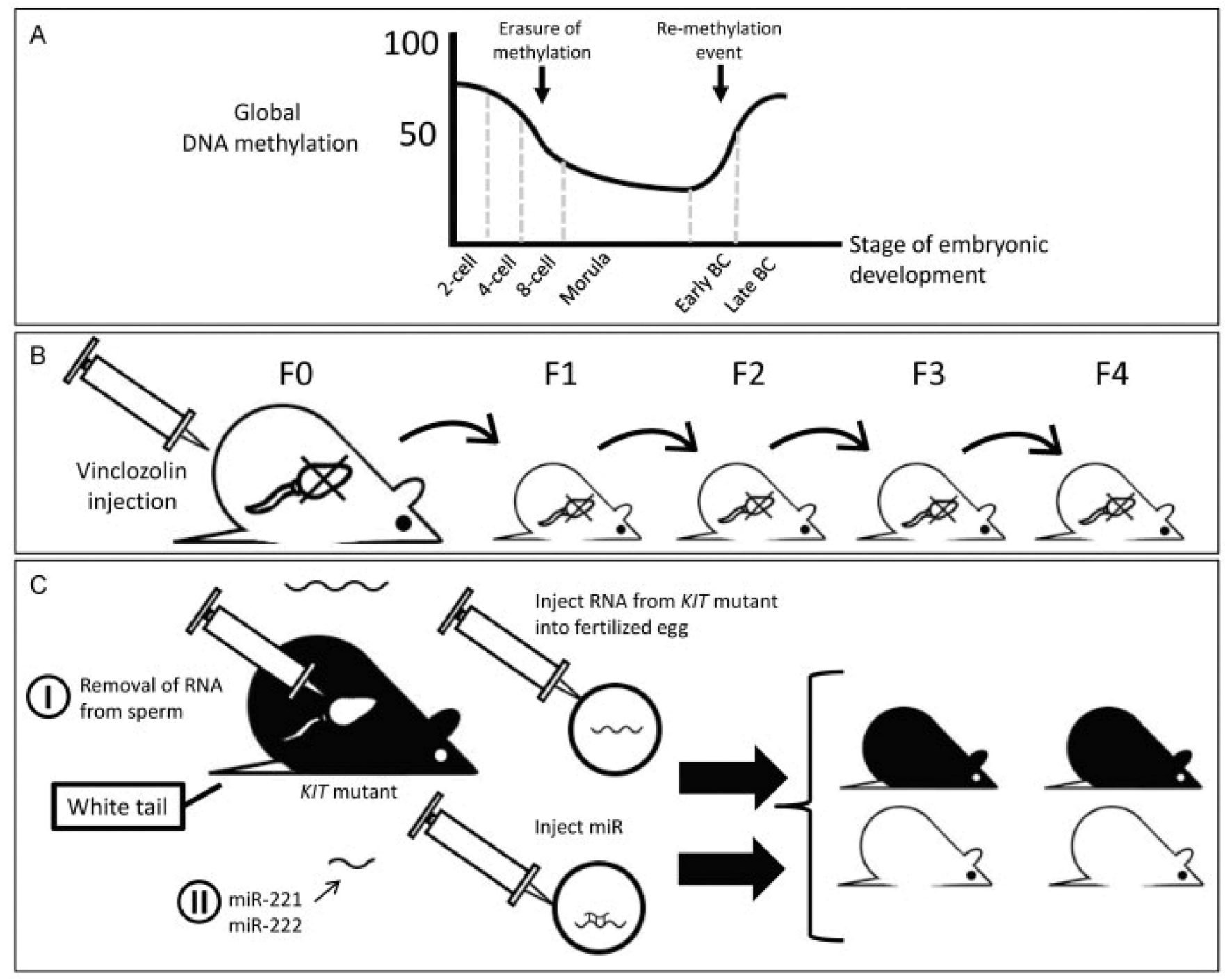

Fig. 5.

Heritability of the epigenome. (A) Embryonic development is characterized by an event that causes erasure of methylation signals belonging to both the oocyte and spermatocyte, leaving approximately $40 \%$ signatures intact. This suggests that the epigenome can be conserved transgenerationally, from parent to child. Demethylation occurs throughout the 2cell to 8-cell stage, thus forming a morula which is predominantly demethylated. At the time of the early BC, re-methylation occurs, providing a means for cell-specific gene expression. (B) Methylation changes may be inheritable, as shown in this mouse model experiment. Vinclozin leads to an increase in spermatogenic cell apoptosis. When injected into a pregestational female mouse (F0), over $90 \%$ of the male offspring of four subsequent generations (F1-F4) develop the same germ cell defect. These changes are associated with differential methylation. (C) NcRNA may also be involved in the transgenerational transmission of the epigenome. It has been shown that nearly $50 \%$ of mice can be driven to develop a stereotypical white tail phenotype through two methods, each involving transmission through RNA. In the first experiment (I), RNA from the sperm of a KIT 
mutant, phenotypically characterized by a white tail, can be injected into a fertilized egg, leading to white-tailed offspring. In the second experiment (II), miR-221 or miR-222, both which can bind to and potentially inhibit KIT transcription, can also lead to white tailed offspring. BC, blastocyst; ncRNA, non-coding RNA; miR, microRNA. 
Table 1

Case-control studies identifying potential exposures in PBC

\begin{tabular}{|c|c|c|c|}
\hline Study) & Country (matching) & $n$ & OR of PBC risk (95\% CI) \\
\hline Howel et al, $2000^{49}$ & UK (age, sex) & $\begin{array}{l}100 \text { PBC } \\
223 \text { controls }\end{array}$ & $\begin{array}{l}2.4(1.3-4.1) \text { ever-smoked } \\
3.5(1.9-6.3) \text { ever-smoked (>20 y) } \\
1.7(0.96-3.0) \text { history of UTI } \\
0.4(0.2-1.0) \text { hysterectomy } \\
4.6(1.2-17.3) \text { history of psoriasis }\end{array}$ \\
\hline Parkh-Patel et al, $2001^{50}$ & $\begin{array}{l}\text { USA (multivariable logistic } \\
\text { regression) }\end{array}$ & $\begin{array}{l}199 \text { PBC } \\
171 \text { sibling controls (S) } \\
141 \text { friend controls }\end{array}$ & $\begin{array}{l}\text { S: } 2.04(1.10-3.78) \text { ever-smoker } \\
\text { S: } 1.86(1.02-3.39) \text { tonsillectomy } \\
\text { S: } 2.12(1.10-4.07) \text { vaginal or UTI }\end{array}$ \\
\hline Gershwin et al, $2005^{51}$ & $\begin{array}{l}\text { USA (age-, sex-, race-, geographical } \\
\text { location) }\end{array}$ & $\begin{array}{l}1,032 \text { PBC } \\
1,041 \text { controls }\end{array}$ & $\begin{array}{l}1.51(1.19-1.92) \text { history of UTI* } \\
1.57(1.29-1.91) \text { ever-smoked* } \\
1.55(1.27-1.88) \text { history of HRT* }\end{array}$ \\
\hline Prince et al, $2010^{59}$ & UK (age, sex) & $\begin{array}{l}318 \text { PBC } \\
\text { (Northeast England, NE) } \\
\text { 2,258 PBC } \\
\text { (Nationwide, NW) } \\
\text { 2,438 controls }\end{array}$ & $\begin{array}{l}\text { NE: } 1.63(1.27-2.09), \text { NW: } 1.57 \\
(1.39-1.78) \text { ever-smoked } \\
\text { NE: } 1.29(1.00-1.80), \text { NW: } 1.25 \\
(1.07-1.46) \text { hair dye use } \\
\text { NE: } 1.90 \text { (1.21-1.91), NW: } 1.33 \\
\text { (1.03-1.73) psoriasis } \\
\text { NE: } 2.06 \text { (1.56-1.73), NW: } 1.80 \\
\text { (1.54-2.11) history of UTI }\end{array}$ \\
\hline Corpechot et al, $2010^{52}$ & $\begin{array}{l}\text { France (age, sex, geographical } \\
\text { location) }\end{array}$ & $\begin{array}{l}222 \text { PBC } \\
509 \text { controls }\end{array}$ & $\begin{array}{l}3.1(2.0-5.0) \text { history of first or second-hand } \\
\text { smoke exposure } 2.7 \text { (2.0-3.7) } \\
\text { history of recurrent UTIs } \\
0.6(0.5-0.8) \text { history of oral contraceptive use }\end{array}$ \\
\hline Lammert et al, $2013^{58}$ & US (multivariable logistic regression) & $\begin{array}{l}522 \text { PBC } \\
616 \text { controls }\end{array}$ & $1.56(1.20-2.02)$ ever-smoker \\
\hline Lammert et al, $2014^{60}$ & $\begin{array}{l}\text { US, Canada (multivariable logistic } \\
\text { regression) }\end{array}$ & $\begin{array}{l}606 \mathrm{PBC} \\
480 \mathrm{PSC} \\
564 \text { controls }\end{array}$ & NS PBC vs. controls \\
\hline
\end{tabular}

Abbreviations: CI, confidence interval; HRT, hormone replacement therapy; IBD, inflammatory bowel disease; NE, Northeast England; NW, nationwide; OR, odds ratio; PBC, primary biliary cholangitis; PSC, primary sclerosing cholangitis; UC, ulcerative colitis; UK, United Kingdom; US, United States; UTI; urinary tract infection. 
Table 2

Case-control studies identifying potential exposures in PSC

\begin{tabular}{|c|c|c|c|}
\hline Study & Country (matching) & $n$ & OR of PSC risk $(95 \% \mathrm{CI})$ \\
\hline Loftus et al, $1996^{64}$ & US (age, sex) & $\begin{array}{l}184 \text { PSC (143 IBD) } \\
184 \text { controls }\end{array}$ & $\begin{array}{l}0.13(0.06-0.30) \text { current- vs. never-smokers } \\
0.41(0.26-0.65) \text { ever- vs. never-smokers } \\
\text { (regardless of IBD) }\end{array}$ \\
\hline $\begin{array}{l}\text { van Erpecum et al, } \\
1996^{65}\end{array}$ & Netherlands & $\begin{array}{l}59 \text { PSC } \\
130 \mathrm{UC} \\
197 \text { nondisease controls }\end{array}$ & $\begin{array}{l}0.37(0.18-0.76) \text { current- vs. never-smokers } \\
1.44(0.67-3.12) \text { appendectomy }\end{array}$ \\
\hline Mitchell et al, $2002^{66}$ & UK & $\begin{array}{l}140 \text { PSC (99 IBD) } \\
170 \text { UC } \\
170 \text { controls }\end{array}$ & $\begin{array}{l}0.17(0.08-0.35) \text { current smokers } \\
0.33(0.21-0.52) \text { ever-smokers } \\
0.45(0.26-0.73) \text { ex-smokers } \\
1.11(0.57-2.2) \text { appendectomy } \\
0.57(0.34-0.96) \text { tonsillectomy }\end{array}$ \\
\hline Andersen et al, $2014^{67}$ & Norway (age, sex) & $\begin{array}{l}240 \text { PSC } \\
245 \text { controls }\end{array}$ & $\begin{array}{l}0.52(0.40-0.83) \text { ever regular coffee consumption } \\
0.33(0.22-0.50) \text { ever-smokers }\end{array}$ \\
\hline Lammert et al, $2014^{68}$ & $\begin{array}{l}\text { US, Canada (multivariable } \\
\text { logistic regression) }\end{array}$ & $\begin{array}{l}480 \text { PSC } \\
606 \text { PBC } \\
564 \text { controls }\end{array}$ & $\begin{array}{l}0.68(0.47-0.99) \text { currently vs. never a coffee } \\
\text { drinker }\end{array}$ \\
\hline Eaton et al, $2015^{63}$ & $\begin{array}{l}\text { US, Canada (multivariable } \\
\text { logistic regression) }\end{array}$ & $\begin{array}{l}1,000 \text { PSC ( } 741 \text { with IBD) } \\
663 \text { controls }\end{array}$ & $\begin{array}{l}0.5(0.4-0.7) \text { ever-smokers (PSC with IBD) } \\
0.9(0.7-1.2) \text { ever-smokers (PSC without IBD) } \\
0.5(0.4-0.7) \text { HRT ever (regardless if IBD status) } \\
1.6(1.2-2.3) \text { recurrent UTIs }\end{array}$ \\
\hline
\end{tabular}

Abbreviations: CI, confidence interval; HRT, hormone replacement therapy; IBD, inflammatory bowel disease; OR, odds ratio; PBC, primary biliary cholangitis; PSC, primary sclerosing cholangitis; UC, ulcerative colitis; UK, United Kingdom; US, United States; UTI; urinary tract infection. 


\section{Table 3}

Studies of the epigenome in PBC

\begin{tabular}{|c|c|c|c|}
\hline Study & Sample origin & Finding & Relevance \\
\hline $\begin{array}{l}\text { Selmi et al, } \\
2014^{72}\end{array}$ & $\begin{array}{l}\text { Discordant twins ( } 3 \text { sets) and } \\
\text { sisters ( } 8 \text { pairs) }\end{array}$ & $\begin{array}{l}\text { Differential methylation twins - } 60 \text { gene regions } \\
\text { sisters - } 14 \text { gene regions } \\
\text { Downregulation of SMARCA1 }\end{array}$ & $\begin{array}{l}\text { First study to show epigenetic } \\
\text { changes in women with PBC. } \\
\text { SMARCA1 associated with } \\
\text { epigenetic control. }\end{array}$ \\
\hline $\begin{array}{l}\text { Lleo et al, } \\
2012^{75}\end{array}$ & $\begin{array}{l}20 \text { women with PBC } 20 \\
\text { healthy women } 9 \text { women } \\
\text { with psoriasis } 9 \text { women with } \\
\text { DM1 }\end{array}$ & $\begin{array}{l}\text { Decreased promoter methylation of CD } 40 \mathrm{~L} \text {, } \\
\text { leading to increased gene expression and high IgM. }\end{array}$ & $\begin{array}{l}\text { Autoimmunity in PBC may in part } \\
\text { be due to demethylation of the } \\
\text { CD40L promoter. }\end{array}$ \\
\hline $\begin{array}{l}\text { Hu et al, } \\
2011^{77}\end{array}$ & $\begin{array}{l}60 \mathrm{PBC} \text { patients ( } 55 \text { women, } \\
5 \text { men) }\end{array}$ & $\begin{array}{l}\text { Increased H4 histone acetylation of promoters for } \\
\text { CD } 40 \text {, LIGHT, IL-17, IFN- } \gamma \text { on auto-reactive T } \\
\text { cells. } \\
\text { Deacetylation of H4 histone of TRAIL, Apo2, } \\
\text { HDAC7A promoters on autoreactive T cells. }\end{array}$ & $\begin{array}{l}\text { Increased expression of molecules } \\
\text { associated with autoimmunity and/or } \\
\text { PBC. } \\
\text { Downregulation of TRAIL may } \\
\text { increase susceptibility to PBC. }\end{array}$ \\
\hline $\begin{array}{l}\text { Mitchell et al, } \\
2011^{89}\end{array}$ & Discordant twins (4 pairs) & $\begin{array}{l}\text { CLIC2 and PIN4 had decreased expression in } \\
\text { subjects with PBC but were partially or variably } \\
\text { methylated with no correlation between } \\
\text { methylation and transcript levels. }\end{array}$ & $\begin{array}{l}\text { Differences in methylation may not } \\
\text { be sufficient to result in changes in } \\
\text { transcription. }\end{array}$ \\
\hline $\begin{array}{l}\text { Miozzo et al, } \\
2007^{91}\end{array}$ & $\begin{array}{l}166 \text { women with PBC } 49 \\
\text { women with HCV (age- } \\
\text { matched) } 177 \text { healthy } \\
\text { women (age-matched) }\end{array}$ & $\begin{array}{l}\text { Active } \mathrm{X} \text { chromosome more likely to come from } \\
\text { one parent in subjects with PBC (usually random) }\end{array}$ & $\begin{array}{l}\text { May lead to a population of immune } \\
\text { cells which are dominated by an X } \\
\text { chromosome from a specific parent, } \\
\text { leading to functional immune } \\
\text { changes. } \\
\text { Random epigenetic silencing of X } \\
\text { chromosomes from different parents } \\
\text { may be a protective mechanism } \\
\text { against disease. }\end{array}$ \\
\hline $\begin{array}{l}\text { Lleo et al, } \\
2013^{92}\end{array}$ & $\begin{array}{l}26 \text { men with PBC } 88 \text { healthy } \\
\text { men (age-matched) }\end{array}$ & $\begin{array}{l}\text { Men with PBC were more likely to have Y } \\
\text { chromosome loss. }\end{array}$ & $\begin{array}{l}\text { Similar relevance to above study on } \\
\text { preferential X chromosome }\end{array}$ \\
\hline $\begin{array}{l}\text { Lleo et al, } \\
2015^{93}\end{array}$ & $\begin{array}{l}30 \text { women with PBC } 30 \\
\text { healthy women (age- } \\
\text { matched) }\end{array}$ & $\begin{array}{l}\text { Differential methylation in the X- chromosome of } \\
\text { CD4 +, CD8+ and CD } 14+\text { cells in } 20,15 \text { and } 19 \\
\text { unique promoters respectively. } \\
\text { Hypomethylation and overexpression of CXCR3 } \\
\text { (involved in Th1 cell differentiation). }\end{array}$ & $\begin{array}{l}\text { May provide a pathogenic rationale } \\
\text { for the importance of } X \text { allele } \\
\text { imbalance as seen in refs }{ }^{91} \text { and }{ }^{92} \text {. }\end{array}$ \\
\hline
\end{tabular}

Abbreviations: CXCR3, chemokine receptor 3; HCV, hepatitis C; PBC, primary biliary cholangitis; SMARCA1, SWI/SNF related, matrix associated, actin dependent regulator of chromatin, subfamily A, member 1; TRAIL, TNF-related apoptosis-inducing ligand. 